\title{
Association of physical activity with sleep health: a systematic review
}

\author{
Associação da atividade física com o sono: uma revisão sistemática
}

\section{AUTHOR'S \\ Andrea Wendt ${ }^{1}$ (iD) \\ Thaynã Ramos Flores ${ }^{1}$ \\ Inacio Crochemore M. da Silva $a^{1,2}$ (ID) \\ Fernando C. Wehrmeister ${ }^{1}$ (D) \\ 1 Federal University of Pelotas, Post-graduate Program in Epidemiology, Pelotas, Rio Grande do Sul, Brazil. \\ 2 Federal University of Pelotas, Superior School of Physical Education, Pelotas, Rio Grande do Sul, Brazil.}

\section{CORRESPONDING}

Andrea Wendt

andreatwendt@gmail.com

Federal University of Pelotas, Post-graduate

Program in Epidemiology. Postal address:

Marechal Deodoro, $1160,3^{\circ}$ floor, Pelotas,

Rio Grande do Sul, Brazil.

CEP: 96020-220.

DOI

$10.12820 /$ rbafs. $23 \mathrm{e} 0057$

\section{(cc) BY-NC-SA}

This work is licensed under the Creative Commons Attribution-NonCommercial-ShareAlike 4.0 International License

\begin{abstract}
The aim of this study was to systematically examine the literature on physical activity and sleep in non-clinical and population-based settings. The inclusion criteria were original studies testing the association between physical activity (as exposure) and sleep (as outcome) in representative samples of the general population, workers, or undergraduate students. Sleep health included sleep duration, sleep quality and insomnia. Studies evaluating samples including only individuals with some disease or a health condition were excluded. A search was performed in the PubMed, Scopus, Lilacs, CINAHL, and SPORTdiscus databases in March 2018. Data extraction was performed using the following items: year, author, country, population, age group, sample size, study design, sleep measurement/definition, physical activity measurement/definition, adjustment and main results. A total of 57 studies were selected, which markedly used heterogeneous instruments to measure physical activity and sleep. The majority were conducted in high-income countries and with cross-sectional design. Physical activity was associated with lower odds of insomnia (observed in 10 of 17 studies), poor sleep quality (observed in 12 of 19 studies) and long sleep duration (observed in 7 of 11 studies). The results about short sleep or continuous sleep duration remain unclear. Physical activity seems to be associated with sleep quality and insomnia, especially among adult and elderly populations in which these outcomes are more usually measured. The short- and long-term effects of physical activity intensities and dose-response on sleep should be better evaluated.
\end{abstract}

Keywords: Epidemiology; Sleep; Motor activity.

RESUMO

Examinar sistematicamente a literatura sobre atividade física e sono em amostras não clínicas e de base populacional. Foram incluídos artigos originais testando a associação entre atividade física (como exposição) e sono (como desfecho) em amostras representativas da população em geral, de trabalhadores ou de universitários. Os desfechos incluídos foram duração do sono, qualidade do sono e insônia. Estudos que avaliaram amostras que incluíram somente individuos com alguma doença ou condição de saúde foram excluídos. A busca foi realizada em março de 2018 nas seguintes bases: PubMed, Scopus, Lilacs, CINAHL e SPORTdiscus. As informaçôes extraídas dos dados foram ano, autor, país, população, faixa etária, tamanho da amostra, delineamento, mensuração e definição das variáveis de desfecho e exposição, variáveis de ajuste e principais resultados. Foram selecionados 57 estudos. A maioria foi conduzida em países de renda alta e com delineamento tranversal. Atividade física foi associada a menor odds de insônia (10 de 17 estudos), qualidade ruim do sono (12 de 19 estudos) e longa duração (7 de 11 estudos). Os resultados sobre curta duração ou duração avaliada de forma contínua permanecem inconclusivos. Os estudos selecionados usaram instrumentos heterogêneos tanto para atividade física quanto sono. Atividade física parece estar associada com qualidade do sono e insônia especialmente entre adultos e idosos onde estes desfechos foram mais frequentemente avaliados. Os efeitos a curto e longo prazo da atividade física em diferentes intensidades ainda precisam ser melhor explorados em futuros estudos originais.

Palavras-chave: Epidemiologia; Sono; Atividade motora.

\section{Introduction}

Sleep influences several physiological processes in humans, such as hormonal secretion, energetic balance, and homeostasis ${ }^{1,2}$. Healthy sleep is associated with reduced risk of chronic diseases, work and traffic accidents, mental disorders, and also with better quality of life and academic achievements ${ }^{1,3-6}$. Therefore, sleep health should be considered as an import public health problem due to its association with general health status and organism homeostasis ${ }^{1}$, and due the considerable proportion of population affected. In the United States, adults showed a prevalence of $13.5 \%$ for short 
sleep duration $(<6 \mathrm{~h})^{7}$, while in Greece, $25.3 \%$ of adult population presented insomnia ${ }^{8}$.

Several sociodemographic and behavioural factors have been shown to influence sleep-related outcomes. In general, sleep disorders are more frequent among women, older adults, white-collar workers, smokers, those with higher alcohol and caffeine consumption, and obese or overweight individuals ${ }^{9-13}$. The American Academy of Sleep Medicine and Sleep Research Society suggest physical activity as a factor that could help to improve sleep health parameters ${ }^{14}$, but evidence at the population level has not yet been clearly identified.

The effects of physical activity on sleep seem to be attributed to body thermoregulation, energy conservation, tissue restoration, hormonal secretion, regulation of the circadian rhythm, and improvement in physical fitness ${ }^{15,16}$. These mechanisms possibly present shortand long-term effects on sleep, but such relationships are difficult to elucidate. A meta-analysis including only experimental studies showed that some effects of physical activity on sleep only exist, or are more pronounced, with a regular frequency of weekly physical activity practice ${ }^{17}$.

It is important to highlight the conceptual differences between physical activity and exercise - a regular activity planned to reach specific aims such as maintaining or increasing health or fitness. The research area of physical activity and sleep began with studies evaluating only exercise and found positive effects on sleep outcomes ${ }^{15,17-19}$, but these effects remain unclear. In observational studies, temporality is an issue which should be considered in the relationship between physical activity and sleep. Some authors have argued there is a bidirectional effect: a bad night of sleep also influences exercise practice on the next day ${ }^{20,21}$.

Most of the literature about the relationship between physical activity and sleep is limited to small experimental studies with volunteers or clinical samples. This limits the generalisation of the results for the entire population, and the pattern of such an association with population levels remains unclear. The effects of overall physical activity (not necessarily structured) also are unknow, since most of literature is based in studies evaluating exercises only. Therefore, this review aims to systematically examine the literature on physical activity and sleep parameters (sleep duration, sleep quality and insomnia) in non-clinical participants from samples with representativeness of a target population. Our hypothesis was that most studies have found a positive relationship between physical activity and sleep health.

\section{Methods}

The search was performed in March 2018 in following databases: PubMed, Scopus, Lilacs, CINAHL, and SPORTdiscus. We used keywords related to physical activity ("physical activity" OR "motor activity" OR "exercise" OR "physical inactivity") in combination with terms for sleep duration sleep quality and insomnia ("sleep health" OR "sleep duration" OR "sleep quality" OR "sleep disorders" OR "Pittsburgh Sleep Quality Index" OR “insomnia” OR "polysomnography” OR "actigraphy”). Each database has its specific rules for combining terms and were adjusted to the search accordingly. We opted for these three outcomes after an exploratory search which identified them as the most frequent outcomes in population-based studies of sleep. Furthermore, these outcomes are the most related to general health.

References selection (title and abstract reading) was performed by two independent reviewers simultaneously and in cases of no consensus about inclusion, a third reviewer was required for the final decision. We emailed the authors' manuscript when full text was not available.

The inclusion criteria were original studies testing the association between physical activity (as exposure) and sleep duration, sleep quality or insomnia (as outcomes) in representative samples of general populations, or specifically samples of workers or undergraduate students representing the target population they aimed at. We excluded studies evaluating physical activity and sleep variables as exposures for other health outcomes, convenience/volunteer-based samples, groups of individuals with some disease or health condition (e.g. obesity, insomnia or other sleep disorders, and/or fibromyalgia) or specific populations (e.g. athletes) and studies where effect measures were not reported. We also focused the review on studies with leisure-time physical activity isolated or combined with other domains. There were no exclusion criteria regarding population age and language. Reference lists from selected studies were also checked. The methodological procedures carried out in this review follow the PRISMA guidelines for systematic reviews ${ }^{22}$.

Data extraction was performed using the following items: year, author, country, population, age group, sample size, study design, sleep measurement/definition, physical activity measurement/definition, adjust- 
ment and main results. Selected studies were evaluated regarding the quality of the report, taking into account (a) response rate report, (b) sleep variable description in text, (c) physical activity variable description in text, (d) adjustment at least for sex/gender, age, and socioeconomic/educational status. We establish this criterion after a discussion about which parameters may capture the quality of studies, since most of the existing scales to measure the quality of studies could not properly be applied in the selected studies.

In order to compare and present the results in a clear way, selected studies were presented as three groups of outcomes: (a) sleep duration, (b) insomnia; and (c) sleep quality. Manuscripts evaluating more than one outcome were included for each outcome. References evaluating more than one dimension of sleep duration (e.g. short and long sleep) were also evaluated separately.

In order to make the results clearer, three categories regarding the association of physical activity with sleep were created:

- Physical activity improves sleep: when physical activity decreases the risk of adverse sleep outcomes (e.g. short sleep, long sleep, insomnia or poor quality) or increased the risk of "good" sleep outcomes (e.g. adequate sleep duration, good sleep quality, and insomnia absence). We also considered as improvement in sleep when physical inactivity or low physical activity increases the risk of "bad" sleep outcomes or decreases the risk of "good" sleep outcomes.

- Physical activity worsens sleep: when physical activity increases the risk of adverse outcomes or decreases the risk of "good" outcomes. Also, it was defined as worsening when physical inactivity or low physical activity decreases the risk of adverse outcomes or increases the risk of "good" outcomes.

\section{Results}

The search identified 16,647 references. Figure 1 presents the number of studies included/excluded in each phase of this review. After all processes, 57 studies were included (Figure 1).

Table 1 presents features of the selected studies. From 57 studies, 28 included population-based samples of adults and elderly ${ }^{7,8,10,13,23-46}$, among them, seven only elderly $23,25,30,32,33,36,37$. Sixteen studies included

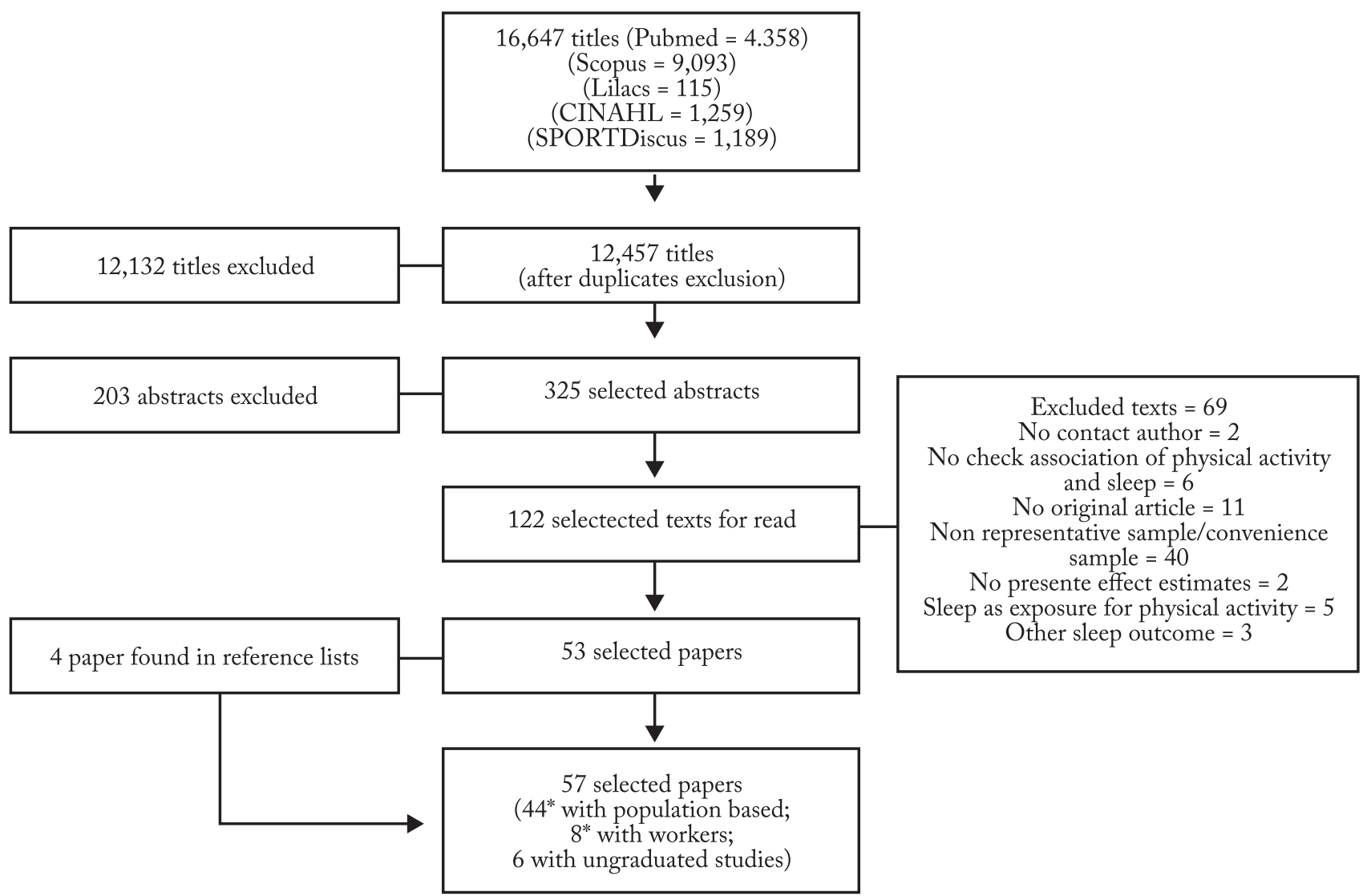

Figure 1 - Flow chart describing the study selection.

*One study had two samples (population-based and workers) and was included two times in the review. 
Table 1 - Description of selected studies $(n=57)$.

\begin{tabular}{|c|c|c|}
\hline Variables & Number of studies (\%) & Reference \\
\hline \multicolumn{3}{|l|}{ Outcome } \\
\hline Sleep duration & $28(49.1)$ & $\begin{array}{l}7,10,13,27,28,29,31,37,38,39,42,43,44,47,48,49,50,52,53,54,55,56,57,58 \\
61,64,65,68\end{array}$ \\
\hline Short sleep & $22(38.6)$ & $7,10,13,27,28,29,37,38,39,42,43,44,47,48,52,53,56,57,58,54,64,65$ \\
\hline Long sleep & $10(17.5)$ & $7,10,13,27,28,29,37,38,42,58$ \\
\hline Continuous/adequate sleep duration & $7(12.3)$ & $31,43,49,50,55,61,68$ \\
\hline Insomnia & $17(29.8)$ & $8,20,22,23,24,25,26,30,33,34,35,36,40,43,45,46,67$ \\
\hline Sleep quality & $19(33.3)$ & $31,32,41,43,44,45,51,55,58,59,60,62,63,66,69,70,71,72,73$ \\
\hline \multicolumn{3}{|l|}{ Sample } \\
\hline Children and adolescents & $16(28.1)$ & $22,47,48,49,50,51,52,53,54,55,56,57,58,59,60,61$ \\
\hline Adults and the elderly & $28(49.1)$ & $\begin{array}{l}7,8,10,13,23,24,25,26,27,28,29,30,31,32,33,34,35,36,37,38,39,40,41,43 \\
44,45,46\end{array}$ \\
\hline Workers & $8(14.0)$ & $7,20,62,63,64,65,66,67$ \\
\hline Undergraduates & $6(10.5)$ & $68,69,70,71,72,73$ \\
\hline \multicolumn{3}{|l|}{ Study design } \\
\hline Cross-sectional & $45(78.9)$ & $\begin{array}{l}7,8,10,13,22,24,25,26,27,28,29,31,33,34,35,38,39,41,42,43,44,46,47,48 \\
50,51,58,59,60,52,53,54,55,56,57,59,61,63,67,68,69,70,71,72,73\end{array}$ \\
\hline Cohort & $12(21.1)$ & $20,23,30,32,36,37,40,45,62,64,65,66$ \\
\hline \multicolumn{3}{|l|}{ Continent } \\
\hline America & $14(24.6)$ & $7,10,24,31,33,38,39,44,45,51,56,58,60,63$ \\
\hline Asia & $25(43.9)$ & $\begin{array}{l}13,22,25,28,29,30,32,37,41,42,46,48,52,53,55,57,62,64,65,66,68,69,70 \\
71,72\end{array}$ \\
\hline Europe & $18(0.32)$ & $7,20,23,26,27,34,35,36,40,43,49,50,54,59,61,67,73$ \\
\hline Oceania & $1(0.0)$ & 47 \\
\hline \multicolumn{3}{|l|}{ Income classification (World Bank) } \\
\hline Middle & $17(29.8)$ & $22,29,32,33,37,41,42,48,53,55,56,57,60,63,69,70,71$ \\
\hline High & $40(70.1)$ & $\begin{array}{l}7,8,10,13,20,23,24,26,27,28,30,31,34,35,36,38,39,40,43,44,45,46,47,49 \\
50,51,52,54,58,59,61,62,64,65,66,67,68,72,73\end{array}$ \\
\hline $\begin{array}{l}\text { Response rate or losses and refusals } \\
\text { reported or } \mathrm{N} \text { for calculations }\end{array}$ & $44(77.2)$ & $\begin{array}{l}7,8,10,20,22,23,25,26,27,28,29,30,32,34,35,36,37,38,40,42,43,45,46,47 \\
48,49,50,51,54,55,57,58,59,62,63,64,65,66,67,69,70,71,72,73\end{array}$ \\
\hline Description of sleep measure & $57(100.0)$ & $\begin{array}{l}7,8,10,13,20,22,23,24,25,26,27,28,29,30,31,32,33,34,35,36,37,38,39,40, \\
41,43,44,45,46,47,48,49,50,51,52,53,54,55,56,57,58,59,60,61,62,63,64,65 \\
66,67,68,69,70,71,72,73\end{array}$ \\
\hline Description of physical activity measure & $41(71.9)$ & $\begin{array}{l}7,8,10,13,20,23,24,26,27,28,30,31,32,33,36,39,40,43,44,45,47,49,50,52 \\
54,55,58,59,60,61,62,64,65,66,67,69,70,71,72,73\end{array}$ \\
\hline $\begin{array}{l}\text { Adjusted/stratified to sex, age and } \\
\text { socioeconomic status }\end{array}$ & $36(63.2)$ & $\begin{array}{l}7,8,13,22,20,27,28,29,30,31,32,36,37,38,39,40,42,43,44,45,46,48,50,53 \\
54,55,58,59,60,63,66,69,70,71,73\end{array}$ \\
\hline \multicolumn{3}{|l|}{ Year of publication } \\
\hline Up to 2000 & $5(8.8)$ & $22,23,24,25,46$ \\
\hline 2001 to 2010 & $11(19.3)$ & $7,8,10,26,27,28,45,47,48,62,68$ \\
\hline 2011 to 2015 & $22(38.6)$ & $13,20,29,30,31,32,33,34,49,50,51,52,53,54,55,61,63,64,65,69,70,71$ \\
\hline $2016+$ & $19(33.3)$ & $35,36,37,38,39,40,41,42,43,44,56,57,58,59,60,66,67,72,73$ \\
\hline \multicolumn{3}{|l|}{ Sample size } \\
\hline Up to 600 & $7(12.3)$ & $25,35,45,47,50,56,59$ \\
\hline 601 to 1500 & $16(28.1)$ & $8,22,23,24,31,32,33,36,58,60,61,62,67,68,70,72$ \\
\hline $1500+$ & $34(59.6)$ & $\begin{array}{l}7,10,13,20,26,27,28,29,30,34,37,38,39,40,41,42,43,44,46,48,49,51,52,53 \\
54,55,57,63,64,65,66,69,71,73\end{array}$ \\
\hline
\end{tabular}

*One study evaluated two samples (one with workers and one of adult population-based).

samples of children and adolescents ${ }^{22,47-61}$. Eight stud-

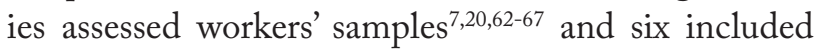
only undergraduate students ${ }^{68-73}$. More than $60 \%$ of studies were published after 2011 and included samples with at least 1,500 individuals.

The majority of the selected studies came from Asia, 
especially China $(n=14)^{22,29,32,37,41,42,48,53,55,57,69-72}$. Around one third of the references (17 out of 57) were studies carried out in middle-income countries according to the World Bank classification, no studies from low-income countries were found. Regarding the study design, 45 were cross-sectional and 12 were cohort studies. The most common outcome evaluated was sleep duration $(\mathrm{n}=28 ; 49.1 \%)$. In these studies, 22 (38.6\%) evaluated short sleep duration, 10 (17.5\%) evaluated long sleep duration and seven (12.3\%) evaluated adequate sleep duration or continuous variable. Insomnia was evaluated in 17 (29.8\%) and sleep quality in 19 (33.3\%) studies.

Around three-quarters of studies $(n=44)$ reported some response rate or made the original sample size available for such calculation. All studies presented a clear outcome description. Regarding physical activity, sixteen did not provide clear information about the instrument used to measure $\mathrm{it}^{22,25,29,34,35,37,41,42,46,48,51,53,56,57,63 \text {, }}$ ${ }^{68}$. Regarding adjustment, only $63.2 \%$ of studies showed adjusted analyses for sex, age, and socioeconomic/educational status (Table 1). Detailed information about each study may be found in Supplementary Table.

Figure 2 shows the results found in this review. Physical activity seems to present a positive effect in long duration of sleep, insomnia and sleep quality, while the possible effect in short and continuous duration of sleep remains unclear.

Figure 3 summarizes the results of the association between physical activity and sleep duration according to some study characteristics. Short sleep duration was assessed in 22 studies $7,10,13,27-29,37-39,42-44,47,48,52-54,56-58,64,65$. The majority of the studies $(\mathrm{n}=13)$ did not show any association $^{7,10,13,27,37,39,43,44,47,48,56,58,65}$. Long sleep duration was assessed in 11 studies. The majority of studies ( $\mathrm{n}=$ 7) showed that physical activity decreases long sleep duration $7,10,13,29,37,38,42$, and four of them did not find any association $7,27,28,58$. Seven studies evaluated continuous or adequate sleep duration, from which four did not find any association ${ }^{31,49,61,68}$.

The effects of physical activity on insomnia or difficulty initiating/maintaining sleep are presented in Figure $4(\mathrm{n}=17)$. All the studies used questionnaires to measure sleep and two used accelerometers to measure physical activity, one of them in adult population-based sample ${ }^{43}$ and another with workers' sample ${ }^{67}$. Regarding the association tested, 10 studies found that physical activity reduces odds/incidence of insomnia $a^{8,22-24,26,30,34,35,40,46}$ and seven did not find any association $^{20,25,33,36,43,45,67}$.

All of the 19 studies that evaluated sleep quality (Figure 4) used questionnaires to measure sleep quality. The most common was the Pittsburgh Sleep quality Index (PSQI), which was used in 13 studies $^{32,41,43,45,51,58,59,62,69-73}$. Only one study measured physical activity using accelerometers ${ }^{43}$. Twelve studies showed physical activity improves sleep quali$\operatorname{ty}^{31,32,41,51,59,62,63,66,69-71,73}$ and in seven no association was found ${ }^{43-45,55,58,60,72}$.

For all outcomes, the patterns of association among the studies with and without adequate adjustment for potential confounders were similar.

\section{Discussion}

This review presented a summary of studies assessing the association between physical activity and sleep duration, sleep quality and insomnia in population-based
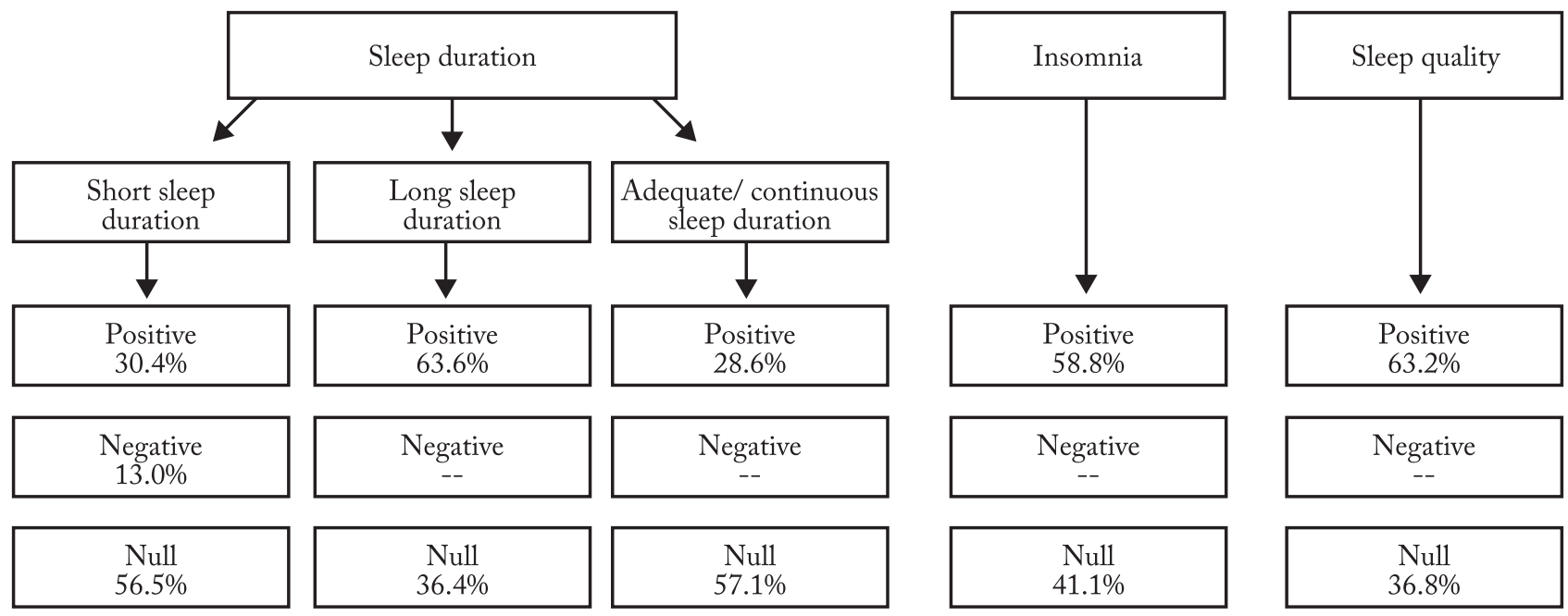

Figure 2 - Summarized results of review.

*Population-based samples. One study used accelerometer and questionnaire to measure physical activity. 


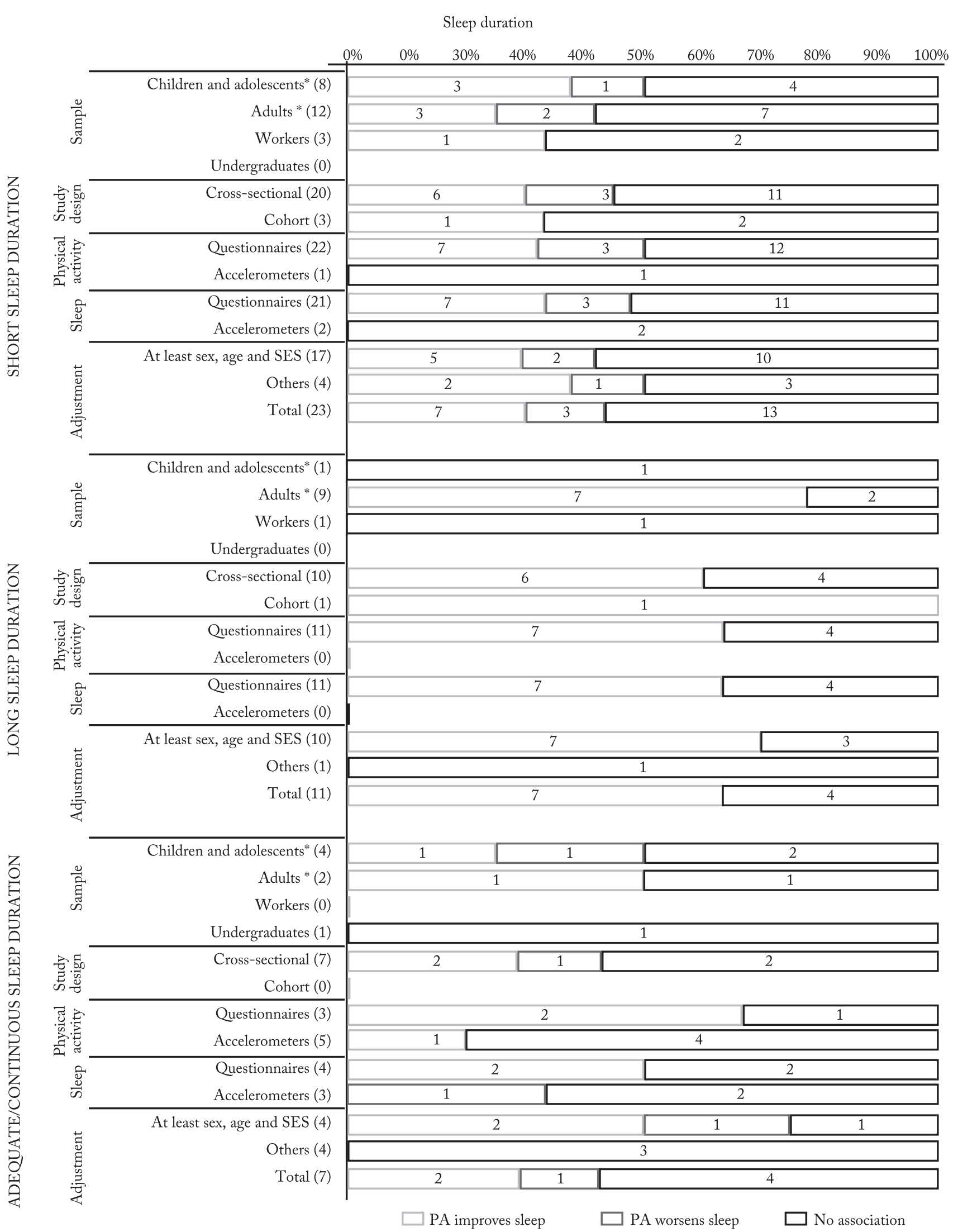

Figure 3 - Effects of physical activity on sleep duration according to study characteristics. 


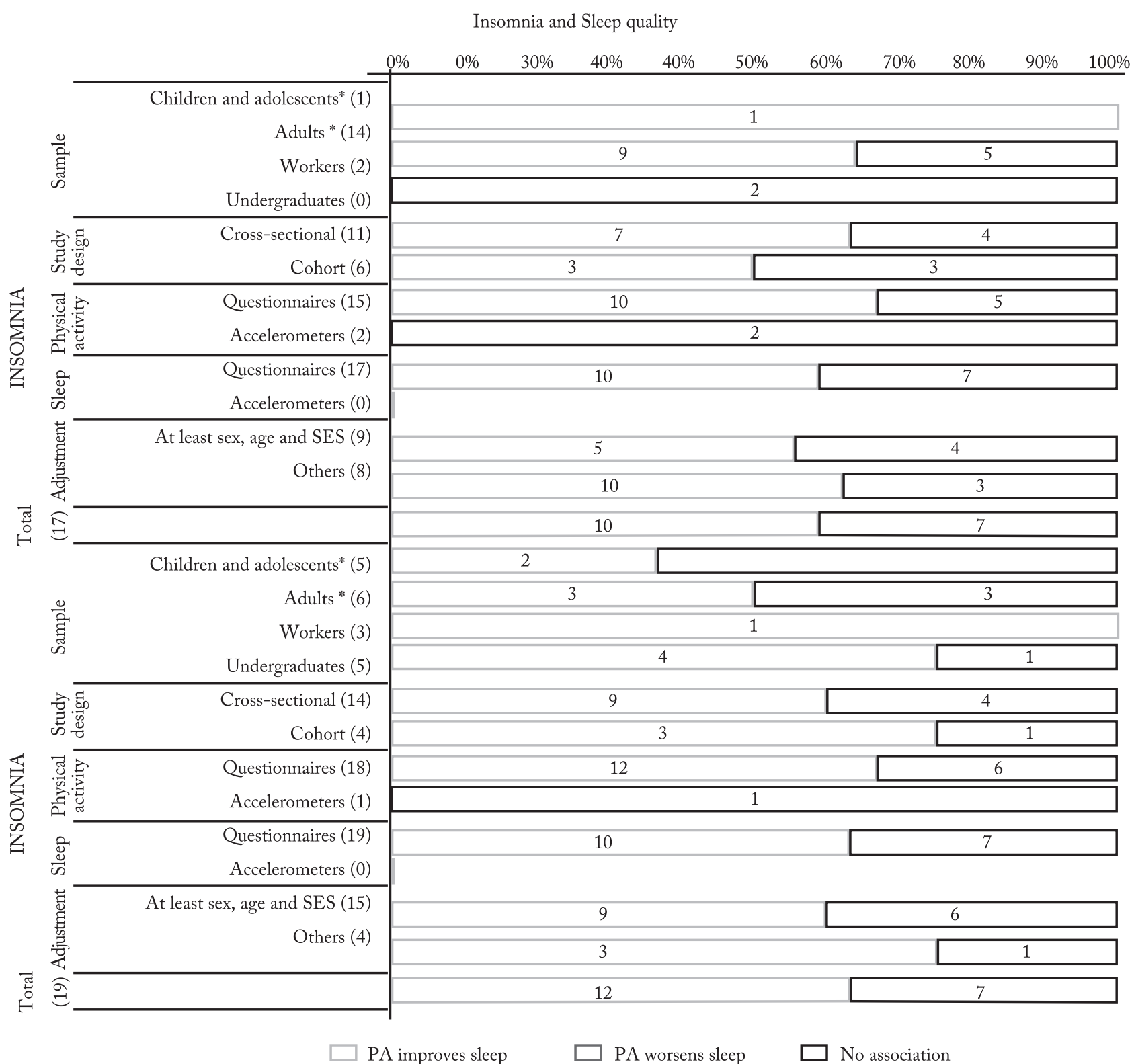

Figure 4- Effects of physical activity on insomnia and sleep quality according to study characteristics.

*Population-based samples

studies and representative samples of workers and undergraduate students. In general, results are inconsistent for short and continuous sleep duration but for long sleep, insomnia and sleep quality, physical activity results seem to play an import role for improvements on these outcomes. The most studies were cross-sectional, were performed in high-income countries, and showed a large variability of instruments for sleep and physical activity.

A review published in 2017 showed that physical activity had an important influence on sleep but some methodological aspects of this review should be highlighted ${ }^{74}$. The main differences between the cited review and the present study were the types of study designs included, population, key-words and the search period. Regarding data bases, it is not clear which were used in Dolezal et. al. ${ }^{74}$ review. Authors have not clarified quality aspects of studies such as method used to measure sleep and physical activity/exercise and adjustment ${ }^{74}$. The present study had no limit on publication years and included only studies with representative samples of general populations, workers, and undergraduates. The other review included any kind of samples, and studies without comparison groups. Furthermore, the previously published systematic review included only papers published from 2013 to 2016. In this period, our review 
detected 23 studies, but only one study was included in both reviews ${ }^{32}$. This may lead to important differences in the inclusion criteria for the studies in each case.

The variety of instruments for physical activity measurement in the selected studies must be highlighted, ranging from lists of activities and accelerometers to questions about meeting the guidelines on exercise frequency during the week. More complete information about physical activity including domain, frequency, intensity, and duration could be important for a better understanding of the relationship. The comparison between studies was difficult due not only to the used instrument, but also to the operational definition of physical activity. Furthermore, separating the effects of physical activity and exercise on sleep was difficult due to the lack of information in the questionnaires/ questions to conclude if exposure was physical activity or exercise. The low accuracy or poor information in questionnaires of physical activity may lead to important bias in results and these measurement errors may reduce the magnitude of the tested association. In addition, the understanding of questionnaires is dependent on other individual and environmental characteristics as socioeconomic status, age and seasonal variation ${ }^{75}$. Studies with poor adjustment or with questionnaires developed to other population than the one studied may contribute to biased findings.

Regarding physical activity intensity, few studies could verify the association of sleep with light, moderate and vigorous physical activity separately. Buman et al. ${ }^{31}$ found positive effects of all intensities combined on different sleep outcomes ${ }^{31}$. Tsunoda et al. ${ }^{64}$ found that light and moderate physical activity decreased, respectively, $14 \%$ and 19\% the risk for short sleep duration, while no effect was identified for moderate physical activity $^{64}$. Energy expenditure of different intensities and how this is captured by physical activity instruments may explain the observed differences ${ }^{15}$. This fact reinforces the need of more studies on this topic.

The dose response relationship is difficult to be assessed in this review as most studies did not provide enough information for such evaluation. Some evidence was available in three studies. Inoue et al. ${ }^{30}$ found an odds ratio of 0.75 to difficulty of initiating sleep with physical activity performed 1 to 2 days in a week compared to none ${ }^{30}$. The odds ratio for 3-4 days was 0.98 and for 5-7 days was $0.66^{30}$. In the same direction, Morgan et al. ${ }^{23}$ in a cohort comprised by elderly individuals, showed that the magnitude of association was almost the same in individuals in medium and low categories of physical activity; they presented an odds of insomnia almost three times higher compared to those in higher category of physical activity ${ }^{23}$. On the other hand, Liu et al. ${ }^{22}$ in a study with adolescents using physical activity frequency (none/ 1-2 times per week/ 3 or more times per week) found an odds ratio 2.7 higher to insomnia in individuals performing 1-2 days of physical activity comparing to three or more times per week. The odds ratio to individuals with no activity days was $3.3^{22}$. This evidence is not consistent; thus, more studies exploring dose-response relationships between physical activity and sleep outcomes are needed.

In terms of sleep assessment, the most common outcome was sleep duration evaluated in 28 studies but with different approaches. Also, in general these studies did not used complex questionnaires but calculated sleep duration from simple questions about sleep onset and sleep end. The recommended sleep duration in adults is seven hours per day ${ }^{14}$ without a maximum limit, although some studies had showed that long sleep may increase risk to mortality and cognitive impairment ${ }^{76-78}$. The sleep duration approach (continuous, adequate, short or long) and its cut off point varied greatly across the studies. Questionnaires to measure insomnia, in general included three questions: difficulty to sleep, difficulty to maintain sleep and too early wake up. These questions were followed by additional questions in some studies. Other structured questionnaires with high reliability were used such as Athens Insomnia Scale (Cronbach's alpha of 0.90) ${ }^{79}$, Jenkins Sleep Questionnaire ${ }^{80}$ and Insomnia Severity Index (Cronbach's alpha of 0.90$)^{81}$. Studies assessing sleep quality mostly used Pittsburgh Sleep Quality, which presents sensitivity of $89.6 \%$ and specificity of $86.5 \%{ }^{82}$.

Literature shows short- and long- effects of exercise on sleep outcomes ${ }^{16,17}$. Authors discuss that lower levels of physical activity may result in sleep architecture changes as there is an increase in duration and a decrease in latency ${ }^{16,17}$. Acute effects of physical activity on sleep are more related to thermoregulation, energy conservation, increases in growth hormone levels, and decreases in cortisol levels ${ }^{15,16}$. On the other hand, regular exercise can potentialize physical activity's effects on sleep outcomes ${ }^{17}$ by increase physical fitness, improve body composition and circadian rhythm regulation, factors which are positively associated with healthy sleep patterns ${ }^{16}$.

Acute effect is very difficult to measure. Cross-sec- 
tional studies cannot capture the essence of short-term effect of physical activity only with questionnaires. This is partly due to all questionnaires are related to habitual physical activity or physical activity in last week, a proxy of regular physical activity. Acute physical activity can only be assessed more easily by accelerometer with analyses of a 24 hours period, despite of challenges related to logistics and resources limitations in use of accelerometers. Recently, some recent studies started to analyse the time spent in different activities over a day ${ }^{83}$ and in the future, studies with large representative samples and considering effect of daily activities performed over sleep at the subsequent night will contribute to a better understanding of the acute effect of physical activity.

Studies evaluating short sleep, in general, did not find any association and those which found an association, were in the direction of reducing proportion of short sleep. However, most studies with long sleep duration found associations showing decreased risk of this outcome. This suggests that, in a given point in sleep duration, the effect of physical activity changes the direction and thus may reduce both short and long sleep. Results of studies evaluating continuous duration were divergent, possibly by the lack of a central reference category (e.g. 7-8 hours). Still, it is possible that physical activity plays a role only in individuals with many hours of sleep. If physical activity has a mechanism of tissue restoration, as previously studies highlight ${ }^{15,16}$, it is possible that active individuals do not need a long sleep period to restoration in comparison with inactive individuals.

It is important to highlight that although the role of physical activity in sleep duration is not so clear, results about sleep quality and insomnia seem to be more consistent. In general, physical activity seems to improve sleep quality and reduce the risk of insomnia, independently of the study design (longitudinal or cross-sectional). A more restorative sleep by thermoregulation, tissue restoration or physical fitness improved by physical activity ${ }^{15,16}$ may lead to better sleep but not necessarily longer or shorter sleep. A new approach in sleep studies encompassing more sleep health aspects than just duration is necessary. Buysse et al. ${ }^{84}$ commented that sleep health has different dimensions associated to different variables ${ }^{84}$. Thus, it is possible that physical activity has a more important association with sleep quality and disorders as insomnia than architecture data, as sleep duration.

Some reports about quality of studies included should be highlight. Although the majority of studies reported data for response rates, in many cases this rate did not reach $60 \%$ of the original sample $8,25,34,58,59,64,66,67$. Moreover, about 20\% of studies did not report rates regarding the original sample of study (sometimes only the analytic sample regarding the collected data) ${ }^{13,24,31-}$ $33,39,41,44,52,56,60,61,68$. In these cases, the possibility of bias is unclear. Furthermore, some specific studies had sampling processes which were likely influenced by sample bias. For example, Ekstead et al ${ }^{61}$ used data from a population that was previously selected for a school intervention ${ }^{61}$. Although the authors comment that the intervention had no effect on the proposed association, as a school-based survey it seems inadequate, since this design did not require the representativeness of a given population $^{61}$. Two studies ${ }^{31,45}$ used sampling processes based on Internet and/or telephone surveys; this can be an important limitation, since not all populations have access to such services. It is probable that individuals who take part in these studies had higher educational levels, socioeconomic status, and access to health services than the general population. Better living conditions are also associated with higher levels of physical activity and lower sleep disorders, but it is probable that these conditions affect the frequency of exposure and outcome but not the association between them.

Regarding the adjustment for possible confounding, most of studies adjusted or stratified for sex and age, but adjustment for socioeconomic or educational status was less frequent. Although the pattern of association comparing studies adjusted to sex, age and socioeconomic status and other studies did not change drastically, these socioeconomic characteristics are important confounding variables for this association. Several authors found that poor individuals or those with lower education had more sleep problems ${ }^{7,8,10,13,27,37}$. Literature has also showed that more disadvantaged groups are more physically inactive ${ }^{85,86}$. Therefore, the results of studies that did not consider socioeconomic or educational status should be carefully observed, mainly in low-income countries where socioeconomic inequalities in health are more pronounced. Few studies present cohort designs and adequate adjusted analyses but, in general, these works showed that the association between physical activity and sleep persist even after the adjustment for possible confounders. Moreover, it should be noted that in this review, cohort studies did not find negative effects of physical activity on all evaluated sleep outcomes.

This review has some limitations such as heteroge- 
neity of data for physical activity which did not allow us to draw more specific conclusions about the magnitude of the effect studied, intensity of physical activity and dose-response relationship. Furthermore, bidirectionality in this theme is relevant. However, this issue is scarce in the literature, due to difficulties in data acquisition, especially. In other hand, this study summarizes results about association of physical activity on sleep in many ages and contexts and identifies the remaining gaps to be addressed in future research on this topic.

In the future, it is relevant to reinforce some topics that should be included in the research agenda: (a) utilisation of comparable instruments for sleep outcomes that do not limit the evaluation to sleep duration only; (b) utilization of clear and comparable operational definitions of physical activity measuring frequency, intensity, and duration; (c) attention to important adjusted variables; and (d) more longitudinal studies with representative samples of low- and lower-middle-income countries are necessary.

Physical activity seems to be positively associated with lower long sleep, and negatively associated with insomnia and poor sleep quality. The results for short and continuous sleep duration are not consistent. The studies included in this review used heterogeneous measures to evaluate both exposures and outcomes and standardization of instruments is needed to obtain combined effect measures.

\section{Conflict of interest}

The authors declare no conflict of interest.

\section{Authors'contribution}

Wendt A and Flores TR, participate of study conception. Wendt A, Flores TR and Wehrmeister FC, participated in search, data selection and extraction. Wendt A, Flores TR, Wehrmeister FC and Silva ICM, wrote and participate in critical review. All authors approved final version of paper.

\section{Acknowledgments}

We acknowledge the National Support Programme for Centres of Excellence (PRONEX-CAPES) and the Brazilian National Research Council (CNPq) for their support. AW and TRF has been funded by CAPES and FCW has been funded by CNPq.

\section{References}

1. Morgan D, Tsai SC. Sleep and the endocrine system. Crit Care Clin. 2015;31(3):403-18.

2. Shukla C, Basheer R. Metabolic signals in sleep regulation: recent insights. Nat Sci Sleep. 2016;8:9-20.
3. Bougard C, Davenne D, Espie S, Moussay S, Leger D. Sleepiness, attention and risk of accidents in powered twowheelers. Sleep Med Rev. 2016;25:40-51.

4. Covassin N, Singh P. Sleep duration and cardiovascular disease risk: epidemiologic and experimental evidence. Sleep Med Clin. 2016;11(1):81-9.

5. Schafer AA, Domingues MR, Dahly DL, Meller FO, Goncalves H, Wehrmeister FC, et al. Sleep duration trajectories and body composition in adolescents: prospective birth cohort study. PloS One. 2016;11(3):e0152348.

6. Wolfson AR, Carskadon MA. Understanding adolescents' sleep patterns and school performance: a critical appraisal. Sleep Med Rev. 2003;7(6):491-506.

7. Stranges S, Dorn JM, Shipley MJ, Kandala N, Trevisan M, Miller MA, et al. Correlates of short and long sleep duration: a cross-cultural comparison between the United Kingdom and the United States: the Whitehall II Study and the Western New York Health Study. Am J Epidemiol. 2008;168(12):1353-64.

8. Paparrigopoulos T, Tzavara C, Theleritis C, Psarros C, Soldatos C, Tountas Y. Insomnia and its correlates in a representative sample of the Greek population. BMC Public Health. 2010;10:531.

9. Garcia AN,Salloum IM.Polysomnographic sleep disturbances in nicotine, caffeine, alcohol, cocaine, opioid, and cannabis use: A focused review. Am J Addict. 2015;24(7):590-8.

10. Krueger PM, Friedman EM. Sleep duration in the United States: a cross-sectional population-based study. Am J Epidemiol. 2009;169(9):1052-63.

11. Phillips B, Ancoli-Israel S. Sleep disorders in the elderly. Sleep Med. 2001;2(2):99-114.

12. Schwartz AR, Patil SP, Laffan AM, Polotsky V, Schneider H, Smith PL. Obesity and obstructive sleep apnea: pathogenic mechanisms and therapeutic approaches. Proc Am Thorac Soc. 2008;5(2):185-92.

13. Yoon HS, Yang JJ, Song M, Lee HW, Han S, Lee SA, et al. Correlates of self-reported sleep duration in middle-aged and elderly Koreans: from the Health Examinees Study. PloS One. 2015;10(5):e0123510.

14. Watson NF, Badr MS, Belenky G, Bliwise DL, Buxton OM, Buysse D, et al. Recommended amount of sleep for a healthy adult: a joint consensus statement of the American Academy of Sleep Medicine and Sleep Research Society. Sleep. 2015;38(6):843-4.

15. Driver HS, Taylor SR. Exercise and sleep. Sleep Med Rev. 2000;4(4):387-402.

16. Uchida S, Shioda K, Morita Y, Kubota C, Ganeko M, Takeda N. Exercise effects on sleep physiology. Front Neurol. 2012;3:48.

17. Kredlow MA, Capozzoli MC, Hearon BA, Calkins AW, Otto MW. The effects of physical activity on sleep: a metaanalytic review. J Behav Med. 2015;38(3):427-49.

18. Montgomery I, Trinder J, Paxton SJ. Energy expenditure and total sleep time: effect of physical exercise. Sleep. 1982;5(2):159-68.

19. O'Connor PJ, Youngstedt SD. Influence of exercise on human sleep. Exer Sport Sci Rev. 1995;23:105-34.

20. Haario P, Rahkonen O, Laaksonen M, Lahelma E, Lallukka T. Bidirectional associations between insomnia symptoms and unhealthy behaviours. J Sleep Res. 2013;22(1):89-95.

21. Pettee Gabriel K, Sternfeld B, Shiroma EJ, Perez A, Cheung J, Lee IM. Bidirectional associations of accelerometerdetermined sedentary behavior and physical activity with reported time in bed: Women's Health Study. Sleep Health. 2017;3(1):49-55. 
22. Liu X, Uchiyama M, Okawa M, Kurita H. Prevalence and correlates of self-reported sleep problems among Chinese adolescents. Sleep. 2000;23(1):27-34.

23. Morgan K, Clarke D. Risk factors for late-life insomnia in a representative general practice sample. $\mathrm{Br} \mathrm{J}$ Gen Pract. 1997;47(416):166-9.

24. Sherrill DL, Kotchou K, Quan SF. Association of physical activity and human sleep disorders. Arch Intern Med. 1998; 28;158(17):1864-8.

25. Ito Y, Tamakoshi A, Yamaki K, Wakai K, Kawamura T, Takagi K, et al. Sleep disturbance and its correlates among elderly Japanese. Arch Gerontol Geriatr. 2000;30(2):85-100.

26. Janson C, Lindberg E, Gislason T, Elmasry A, Boman G. Insomnia in men-a 10-year prospective population based study. Sleep. 2001;24(4):425-30.

27. Kronholm E, Härmä M, Hublin C, Aro AR, Partonen T. Self-reported sleep duration in Finnish general population. J Sleep Res. 2006;15(3):276-90.

28. Park S, Cho MJE, Chang SM, Bae JN, Jeon HJ, Cho SJ, et al. Relationships of sleep duration with sociodemographic and health-related factors, psychiatric disorders and sleep disturbances in a community sample of Korean adults. J Sleep Res. 2010;19(4):567-77.

29. Tu X, Cai H, Gao YT, Wu X, Ji BT, Yang G, et al. Sleep duration and its correlates in middle-aged and elderly Chinese women: The Shanghai Women's Health Study. Sleep Med. 2012;13(9):1138-45.

30. Inoue S, Yorifuji T, Sugiyama M, Ohta T, Ishikawa-Takata K, Doi H. Does habitual physical activity prevent insomnia? A cross-sectional and longitudinal study of elderly japanese. J Aging Phys Act. 2013;21(2):119-39.

31. Buman MF, Phillips BA, Youngstedt SD, Kline CE, Hirshkowitz M. Does nighttime exercise really disturb sleep? Results from the 2013 National Sleep Foundation Sleep in America Poll. Sleep Med. 2014;15(7):755-61.

32. Chen LJ, Fox KR, Sun WJ, Lo MK, Ku PW. Prospective associations between different categories of physical activity and insomnia in older adults. Int J Sport Psychol. 2014;45(3):173-86.

33. Monteiro NT, Neri AL, Ceolim MF. Insomnia symptoms, daytime naps and physical leisure activities in the elderly: FIBRA study Campinas. Rev Esc Enferm USP. 2014;48(2):239-46.

34. Uhlig BL, Sand T, Ødegård SS, Hagen K. Prevalence and associated factors of DSM-V insomnia in Norway: The Nord-Trøndelag Health Study (HUNT 3). Sleep Med. 2014;15(6):708-13.

35. Fusz K, Faludi B, Pusztai D, Sebok N, Olah A. Insomnia and habits to help to fall asleep among adults. Orv Hetil. 2016;157(49):1955-9.

36. Hartescu I, Morgan K, Stevinson CD. Sleep Quality and recommended levels of physical activity in older people. J Aging Phys Act. 2016;24(2):201-6.

37. Smagula S, Koh W, Wang R, Yuan JM. Chronic disease and lifestyle factors associated with change in sleep duration among older adults in the Singapore Chinese Health Study. J Sleep Res. 2016;25(1):57-61.

38. Wu Y, Yang L, Shen X, Zhai L, Fan C, Zhang D. Effect of leisure-time aerobic exercise and muscle strength activity on sleep duration: results from the 2012 National Health Interview Survey. J Public Health. 2016;24(2):117-24.

39. Murillo R, Lambiase MJ, Rockette-Wagner BJ, Kriska AM, Haibach JP, Thurston RC. Racial/ethnic differences in the associations between physical activity and sleep duration: a population-based study.J Phys Act Health. 2017;14(2):138-44.
40. Sporndly-Nees S, Asenlof P, Lindberg E. High or increasing levels of physical activity protect women from future insomnia. Sleep Med. 2017;32:22-7.

41. Zhang HS, Li Y, Mo HY, Qiu DX, Zhao J, Luo JL, et al. A community-based cross-sectional study of sleep quality in middle-aged and older adults. Qual Life Res. 2017;26(4):923-33.

42. Wang S, Li B, Wu Y, Ungvari GS, Ng CH, Fu Y, et al. Relationship of sleep duration with sociodemographic characteristics, lifestyle, mental health, and chronic diseases in a large Chinese adult population. J Clin Sleep Med. 2017;13(3):377-84.

43. Gubelmann C, Heinzer R, Haba-Rubio J, Vollenweider P, Marques-Vidal P. physical activity is associated with higher sleep efficiency in the general population: The CoLaus Study. Sleep. 2018;41(7).

44. Vézina-Im L, Lebel A, Gagnon P, Nicklas TA, Baranowski T. Individual correlates of sleep among childbearing age women in Canada. Behav Sleep Med. 2018:1-12.

45. LeBlanc M, Merette C, Savard J, Ivers H, Baillargeon L, Morin CM. Incidence and risk factors of insomnia in a population-based sample. Sleep. 2009;32(8):1027-37.

46. Kim K, Uchiyama M, Okawa M, Liu X, Ogihara R. An epidemiological study of insomnia among the Japanese general population. Sleep. 2000;23(1):41-7.

47. Nixon GM, Thompson JM, Han DY, Becroft DM, Clark PM, Robinson E, et al. Short sleep duration in middle childhood: risk factors and consequences. Sleep. 2008;31(1):71-8.

48. Li S, Zhu S, Jin X, Yan C, Wu S, Jiang F, et al. Risk factors associated with short sleep duration among Chinese schoolaged children. Sleep Med. 2010;11(9):907-16.

49. Hense S, Barba G, Pohlabeln H, De Henauw S, Marild S, Molnar D, et al. Factors that influence weekday sleep duration in European children. Sleep. 2011;34(5):633-9.

50. Pesonen AK, Sjöstén NM, Matthews KA, Heinonen K, Martikainen S, Kajantie E, et al. Temporal associations between daytime physical activity and sleep in children. PloS One. 2011;6(8):e22958.

51. Narang I, Manlhiot C, Davies-Shaw J, Gibson D, Chahal N, Stearne K, et al. Sleep disturbance and cardiovascular risk in adolescents. CMAJ. 2012;184(17):E913-20.

52. Al-Hazzaa HM, Musaiger AO, Abahussain NA, Al-Sobayel HI, Qahwaji DM. Lifestyle correlates of self-reported sleep duration among Saudi adolescents: a multicentre schoolbased cross-sectional study. Child Care Health Devt. 2014;40(4):533-42.

53. Chen T, Wu Z, Shen Z, Zhang J, Shen X, Li S. Sleep duration in Chinese adolescents: biological, environmental, and behavioral predictors. Sleep Med. 2014; 15(11):1345-53.

54. Stea TH, Knutsen T, Torstveit MK. Association between short time in bed, health-risk behaviors and poor academic achievement among Norwegian adolescents. Sleep Med. 2014;15(6):666-71.

55. Jiang X, Hardy LL, Baur LA, Ding D, Wang L, Shi H. Sleep duration, schedule and quality among urban Chinese children and adolescents: associations with routine afterschool activities. PloS One. 2015;10(1):e0115326.

56. Felden ÉPG, Filipin D, Barbosa DG, Andrade RD, Meyer C, Louzada FM. Factors associated with short sleep duration in adolescents. Rev Paul Pediatr. 2016;34(1):64-70.

57. Gong QH, Li H, Zhang XH, Zhang T, Cui J, Xu GZ. Associations between sleep duration and physical activity and dietary behaviors in Chinese adolescents: results from the Youth Behavioral Risk Factor Surveys of 2015. Sleep Med. 2017;37:168-73. 
58. Kakinami L, O'Loughlin EK, Brunet J, Dugas EN, Constantin E, Sabiston CM, et al. Associations between physical activity and sedentary behavior with sleep quality and quantity in young adults. Sleep Health. 2017;3(1):56-61.

59. Herring MP, Monroe DC, Kline CE, O'Connor PJ, MacDonncha C. Sleep quality moderates the association between physical activity frequency and feelings of energy and fatigue in adolescents. Eur Child Adolesc Psychiatry. 2018;27(11):1425-32.

60. Lima TR, Silva DAS. Association of sleep quality with sociodemographic factors and lifestyle in adolescents from southern Brazil. World J Pediatr. 2018;14(4):383-391.

61. Ekstedt M, Nyberg G, Ingre M, Ekblom O, Marcus C. Sleep, physical activity and BMI in six to ten-year-old children measured by accelerometry: a cross-sectional study. Int J Behav Nutr Phys Act. 2013;10:82.

62. Saeki U, Nasermoaddeli A, Sekine M, Kagamimori S. Relationships of positive and negative affectivity to sleep quality in Japanese civil servants: 3-year follow-up study. Sangyo Eiseigaku Zasshi. 2008;50(6):219-25.

63. Hoefelmann LP, Lopes Ada S, Silva KS, Silva SG, Cabral LG, Nahas MV. Lifestyle, self-reported morbidities, and poor sleep quality among Brazilian workers. Sleep Med. 2012;13(9):1198-201.

64. Tsunoda K, Kai Y, Kitano N, Uchida K, Kuchiki T, Okura $\mathrm{T}$, et al. Influence of physical activity on sleep duration and quality: A prospective cohort study. Bull Phys Fitness Res Inst. 2014(112):8-17.

65. Tsunoda K, Kitano N, KaiY,Uchida K, Kuchiki T, Okura T, et al. Prospective study of physical activity and sleep in middleaged and older adults. Am J Prev Med. 2015;48(6):662-73.

66. Kitano N, Tsunoda K, Kai Y, Jindo T, Uchida K, Onodera $Y$, et al. Impact of leisure-time physical activity pattern on subjective sleep quality in Japanese workers: A 1-year followup study. Bull Phys Fitness Res Inst. 2017;115:15-22.

67. Skarpsno ES, Mork PJ, Lund Nilsen TI, Jørgensen MB, Holtermann A. Objectively measured occupational and leisure-time physical activity: cross-sectional associations with sleep problems. Scand J Wor Environ Health. 2018;44(2):202-11.

68. Ban DJ, Lee TJ. Sleep duration, subjective sleep disturbances and associated factors among university students in Korea. J Korean Med Sci. 2001;16(4):475-80.

69. Yu QC, Ma WJ, Zou YF, Chen GM, Yao YY, Su PY, et al. Impact of evening exercise on college students' sleep quality. Zhonghua Yu Fang Yi Xue Za Zhi. 2013;47(6):542-6.

70. Feng Q, Zhang QL, Du Y, Ye YL, He QQ. Associations of physical activity, screen time with depression, anxiety and sleep quality among Chinese college freshmen. PloS One. 2014;9(6):e100914.

71. Wu X, Tao S, Zhang Y, Zhang S, Tao F. Low physical activity and high screen time can increase the risks of mental health problems and poor sleep quality among Chinese college students. PloS One. 2015;10(3):e0119607.

72. Chang SP, Shih KS, Chi CP, Chang CM, Hwang KL, Chen YH. Association between exercise participation and quality of sleep and life among university students in Taiwan. Asia Pac J Public Health. 2016;28(4):356-67.

73. Štefan L, Krističević T, Sporiš G. The associations of selfreported physical fitness and physical activity with sleep quality in young adults: A population-based study. Ment Health Phys Act 2018;14:131-5.
74. Dolezal BA, Neufeld EV, Boland DM, Martin JL, Cooper CB. Interrelationship between sleep and exercise: a systematic review. Adv Prev Med. 2017;2017:1364387.

75. Sylvia LG, Bernstein EE, Hubbard JL, Keating L, Anderson EJ. Practical guide to measuring physical activity.J Acad Nutr Diet. 2014;114(2):199-208.

76. Cappuccio FP, D’Elia L, Strazzullo P, Miller MA. Sleep duration and all-cause mortality: a systematic review and meta-analysis of prospective studies. Sleep. 2010;33(5):585-92.

77. Lo JC, Groeger JA, Cheng GH, Dijk DJ, Chee MW. Selfreported sleep duration and cognitive performance in older adults: a systematic review and meta-analysis. Sleep Med. 2016;17:87-98.

78. Shen X, Wu Y, Zhang D. Nighttime sleep duration, 24hour sleep duration and risk of all-cause mortality among adults: a meta-analysis of prospective cohort studies. Sci Rep. 2016;6:21480.

79. Soldatos CR, Dikeos DG, Paparrigopoulos TJ. Athens Insomnia Scale: validation of an instrument based on ICD10 criteria. J Psychosom Res. 2000;48(6):555-60.

80. Shahid A., Wilkinson K., Marcu S., Shapiro C. M. Springer NY, NY. Jenkins Sleep Scale. In: . STOP, THAT and One Hundred Other Sleep Scales. NY: Springer; 2011.

81. Morin CM, Belleville G, Belanger L, Ivers H. The Insomnia Severity Index: psychometric indicators to detect insomnia cases and evaluate treatment response. Sleep. 2011;34(5):601-8.

82. Buysse DJ, Reynolds CF, 3rd, Monk TH, Berman SR, Kupfer DJ. The Pittsburgh Sleep Quality Index: a new instrument for psychiatric practice and research. Psychiatry Res. 1989;28(2):193-213.

83. Dumuid D, Stanford TE, Martin-Fernandez JA, Pedisic Z, Maher CA, Lewis LK, et al. Compositional data analysis for physical activity, sedentary time and sleep research. Stat Methods Med Res. 2017:27(12):3726-38

84. Buysse DJ. Sleep health: can we define it? Does it matter? Sleep. 2014;37(1):9-17.

85. Beenackers MA, Kamphuis CB, Giskes K, Brug J, Kunst AE, Burdorf A, et al. Socioeconomic inequalities in occupational, leisure-time, and transport related physical activity among European adults: a systematic review. Int J Behav Nutr Phys Act. 2012;9:116.

86. Drenowatz C, Eisenmann JC, Pfeiffer KA, Welk G, Heelan $\mathrm{K}$, Gentile $\mathrm{D}$, et al. Influence of socio-economic status on habitual physical activity and sedentary behavior in 8- to 11year old children. BMC Public Health. 2010;10:214.

Recebido: $15 / 11 / 2018$

Aprovado: 02/05/2019 
Supplementary Table - Detailed information of selected studies $(n=57)$.

\begin{tabular}{|c|c|c|c|c|}
\hline Author, Design & $\begin{array}{l}\text { Population, } \\
\text { country }\end{array}$ & Sleep measures & Physical activity measures & Main results \\
\hline $\begin{array}{l}\text { Morgan \& } \\
\text { Clarke }^{23} \\
\text { Longitudinal }\end{array}$ & $\begin{array}{l}\text { Elderly }(65+ \\
\text { years) } \\
\mathrm{N} \text { in follow-up } \\
=690 \\
\text { England }\end{array}$ & $\begin{array}{l}\text { Questionnaire: } \\
\text { "Do you ever have problems } \\
\text { sleeping?" } \\
\text { If participant answer "often" or } \\
\text { "all the time", it was considerate } \\
\text { insomnia. } \\
\text { The authors calculated the } \\
\text { insomnia incidence. }\end{array}$ & $\begin{array}{l}\text { Questionnaire: } \\
\text { Habitual PA: indoor, outdoor, social } \\
\text { and practical activities. } \\
\text { The questionnaire was analyzed with } \\
\text { a pca (only the first component was } \\
\text { used). } \\
\text { Score continuous of a pca analyze } \\
\text { (divided in PA high, intermediate, low). } \\
\text { The low category was the reference. }\end{array}$ & $\begin{array}{l}\text { Comparing to high PA, individuals in } \\
\text { intermediate PA category, presented } \\
\text { odds } 2.89 \text { higher to insomnia (CI95\%: } \\
\text { 1.91-3.62). } \\
\text { Individuals in low PA category } \\
\text { presented odds } 2.94 \text { higher for } \\
\text { insomnia comparing to high PA (CI } \\
95 \%: 2.14-3.64) \text {. }\end{array}$ \\
\hline Cross-sectional & $\begin{array}{l}\text { Adults }(40+ \\
\text { years }) \\
\mathrm{N}=722 \\
\text { USA }\end{array}$ & $\begin{array}{l}\text { Questionnaire: } \\
\text { "Have you ever been troubled by } \\
\text { any of the following problems: } \\
\text { a. trouble falling asleep } \\
\text { b. trouble staying asleep } \\
\text { c. not enough sleep } \\
\text { d. waking up too early and not } \\
\text { being able to get back to sleep" } \\
\text { If participant answer yes at least } \\
\text { one of } 4 \text { questions was considered } \\
\text { insomnia. }\end{array}$ & $\begin{array}{l}\text { Questionnaire: } \\
\text { a. "How many city blocks or equivalent } \\
\text { do you regularly walk each day? What } \\
\text { is your pace of walking?" } \\
\text { b. "Are you participating in any exercise } \\
\text { program specifically designed to } \\
\text { improve your physical health?" } \\
\text { c. "On a usual weekday/weekend day, } \\
\text { how much time do you spend doing } \\
\text { vigorous activity (sports, jogging, } \\
\text { sustained swimming, brisk walking, or } \\
\text { bicycling)?". } \\
\text { The answers generated the follow } \\
\text { variables: } \\
\text { a. Walk >6 blocks per day at a casual } \\
\text { pace or at a brisk pace; } \\
\text { b. Participate in exercise program } \\
\text { c. Regular activity at least once a week } \\
\text { d. Vigorous activity (> 1h/day) in } \\
\text { weekdays and weekends. }\end{array}$ & $\begin{array}{l}\text { Walk }>6 \text { blocks per day at average pace } \\
\text { decreased the odds of insomnia in } 0.67 \\
\text { times (CI 95\%: } 0.46-0.97 \text { ). } \\
\text { Only for men, walk }>6 \text { blocks per } \\
\text { day at a brisk pace, decrease the odds } \\
\text { of insomnia in } 0.50 \text { times (CI } 95 \% \text { : } \\
0.27-0.93 \text { ). } \\
\text { Participating in exercise program } \\
\text { decreased the odds of insomnia in } 0.52 \\
\text { times (CI 95\%: } 0.30-0.92 \text { ). } \\
\text { Regular activity at least once a week } \\
\text { decreased the odds of insomnia in } 0.71 \\
\text { times (CI 95\%: } 0.50-0.99 \text { ). } \\
\text { Only for women, vigorous activity in } \\
\text { weekends and participate in exercise } \\
\text { program (interaction) increased the } \\
\text { odds of insomnia in } 2.16 \text { times (1.02- } \\
4.58 \text { ). }\end{array}$ \\
\hline $\begin{array}{l}\text { Ito et al. }{ }^{25} \\
\text { Cross-sectional }\end{array}$ & $\begin{array}{l}\text { Adults }(65+ \\
\text { years }) \\
\mathrm{N}=518 \\
\text { Japan }\end{array}$ & $\begin{array}{l}\text { Questionnaire: } \\
\text { a. "How many hours do you sleep } \\
\text { at night on average?" } \\
\text { b. "How long does it take from } \\
\text { going to bed to falling asleep? } \\
\text { (answer: }<10 \text { min, } 10-30 \text { min, } \\
30-60 \text { min, or }>60 \text { min)" } \\
\text { c. "How many times do you } \\
\text { usually wake up at night? (answer: } \\
\text { never, once, twice, or three times } \\
\text { or more)" } \\
\text { d. "How do you feel when you } \\
\text { wake up in the morning? (answer: } \\
\text { good or bad)" } \\
\text { Insomnia was evaluated checking } \\
\text { the follow aspects: } \\
\text { a. difficulty in falling asleep } \\
\text { (difference between bedtime and } \\
\text { time of falling asleep exceeded } \\
30 \text { min) } \\
\text { b. Frequent awakening at night } \\
\text { (more than twice) } \\
\text { c. feeling not rested in the } \\
\text { morning (answer "bad" to this } \\
\text { question). }\end{array}$ & $\begin{array}{l}\text { Questionnaire: no information. } \\
\text { The variable generated was "PA more } \\
\text { than once a week". }\end{array}$ & $\begin{array}{l}\text { No association to any variable related } \\
\text { to insomnia. }\end{array}$ \\
\hline
\end{tabular}

Continue... 
... continue

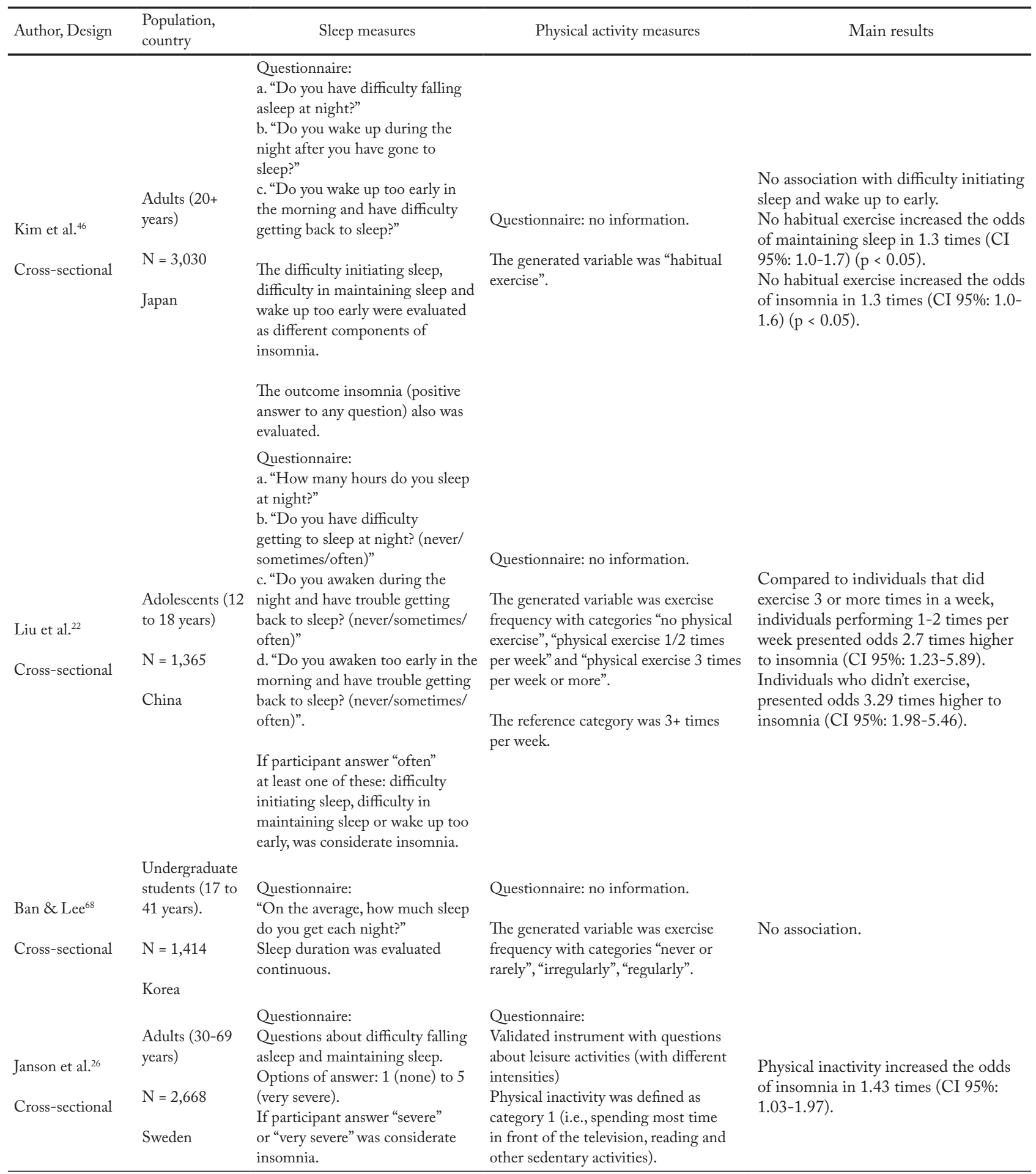

Continue... 
... continue

\begin{tabular}{|c|c|c|c|c|}
\hline Author, Design & $\begin{array}{l}\text { Population, } \\
\text { country }\end{array}$ & Sleep measures & Physical activity measures & Main results \\
\hline \multirow{3}{*}{$\begin{array}{l}\text { Kronholm et al. } .^{27} \\
\text { Cross-sectional }\end{array}$} & $\begin{array}{l}\text { Adults (18+ } \\
\text { years) }\end{array}$ & $\begin{array}{l}\text { Questionnaire: } \\
\text { a. Duration: } \\
\text { "How many hours do you sleep in } \\
24 \text { hours?" } \\
\text { b. Insomnia: } \\
\text { "Have you had some of the } \\
\text { following usual } \\
\text { symptoms and troubles within }\end{array}$ & $\begin{array}{l}\text { Questionnaire: } \\
\text { PA in leisure-time. }\end{array}$ & \multirow{3}{*}{$\begin{array}{l}\text { No association in the best adjusted } \\
\text { model. }\end{array}$} \\
\hline & $\mathrm{N}=7,551$ & $\begin{array}{l}\text { the last month (30 days) sleeping } \\
\text { disorders or insomnia?" }\end{array}$ & \multirow{2}{*}{$\begin{array}{l}\text { The variable generate result in follow } \\
\text { categories: "not much", ">4 h/week", } \\
\text { "exercise >3h/week" and "competition } \\
\text { sports". }\end{array}$} & \\
\hline & Finland & $\begin{array}{l}\text { Short sleepers: } \leq 6 \text { hours } \\
\text { Mid-range sleepers: } 7-8 \text { hours } \\
\text { Long sleepers: } 9+\text { +hours } \\
\text { Sleep duration continuous also } \\
\text { was used (to dose-response). }\end{array}$ & & \\
\hline \multirow{5}{*}{$\begin{array}{l}\text { Nixon et al. }{ }^{47} \\
\text { Cross-sectional }\end{array}$} & & Insomnia: yes/no. & & \multirow{5}{*}{ No association. } \\
\hline & $\begin{array}{l}\text { Children }(7 \\
\text { years) }\end{array}$ & $\begin{array}{l}\text { Accelerometry: MTI } \\
\text { accelerometer based on sleep log. } \\
\text { Continuous variables: } \\
\text { Sleep onset time was defined as } \\
\text { the first } 3 \text { consecutive minutes of } \\
\text { sleep in the scoring interval after } \\
\text { the reported bedtime. }\end{array}$ & $\begin{array}{l}\text { Questionnaire: } \\
\text { a. "Compared with other children, does } \\
\text { your child run around outside?" Possible } \\
\text { responses were "A lot," "the same," or } \\
\text { "less." } \\
\text { b. How many times a week does your } \\
\text { child engage in vigorous physical } \\
\text { activity long enough to make him/her } \\
\text { breathe hard?" Possible responses were } \\
\text { "Never" or "occasionally," "once or twice } \\
\text { a week," "three or more times a week." } \\
\text { c. "During a normal week, how many } \\
\text { hours a day ( } 24 \text { hours) does your child } \\
\text { watch television?” Possible responses } \\
\text { were "<1," "1-3," or “>3 hours." }\end{array}$ & \\
\hline & $\mathrm{N}=519$ & $\begin{array}{l}\text { Sleep end time was defined as } \\
\text { the time of the last } 5 \text { consecutive }\end{array}$ & Accelerometry: MTI accelerometer & \\
\hline & New Zeeland & $\begin{array}{l}\text { minutes of sleep prior to the } \\
\text { reported rise time. } \\
\text { Sleep period time (sleep duration) } \\
\text { was the time from sleep onset to } \\
\text { sleep end time. }\end{array}$ & $\begin{array}{l}\text { The generate variables were: } \\
\text { a. Runs around a lot outside (parent } \\
\text { report) } \\
\text { b. Vigorous activity at least once a } \\
\text { week (parent report) }\end{array}$ & \\
\hline & & Short sleep: $<9 \mathrm{~h}$. & $\begin{array}{l}\text { c. Total daytime movement counts } \\
\text { (change in sleep duration per } 105 \\
\text { counts) } \\
\text { d. Mean daytime movement counts/ } \\
\text { min (change in sleep duration per } \\
10^{2} \text { counts/min } \\
\text { e. sedentary (min) } \\
\text { f. moderate (min) } \\
\text { g. vigorous (min). }\end{array}$ & \\
\hline \multirow{4}{*}{$\begin{array}{l}\text { Saeki et al. }{ }^{62} \\
\text { Longitudinal }\end{array}$} & $\begin{array}{l}\text { Workers (age } \\
\text { average: } 45.8\end{array}$ & & Questionnaire: exercise frequency. & \multirow{4}{*}{$\begin{array}{l}\text { Regular exercise increases the odds of } \\
\text { good sleep quality } 3 \text { years after in } 1.88 \\
\text { times (CI 95\%: 1.29-2.75). }\end{array}$} \\
\hline & & Sleep quality: PSQI & Weekly frequency was classified & \\
\hline & $\mathrm{N}=827$ & Poor sleep quality $\geq 6$ points. & $\begin{array}{l}\text { as "regular exercise" and monthly } \\
\text { frequency or less as "not practicing". }\end{array}$ & \\
\hline & Japan & & & \\
\hline
\end{tabular}

Continue... 
... continue

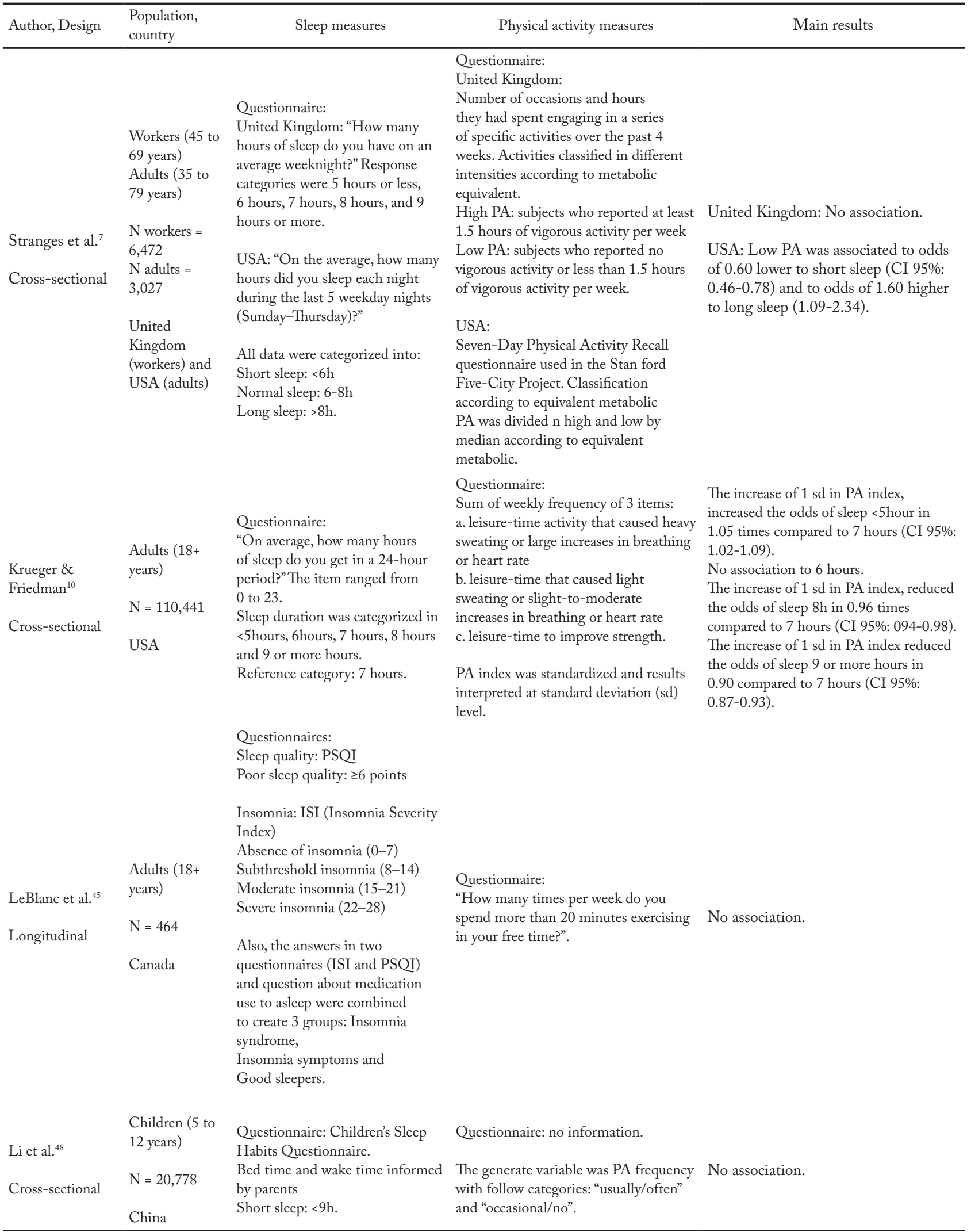

Continue... 


\begin{tabular}{|c|c|c|c|c|}
\hline Author, Design & $\begin{array}{l}\text { Population, } \\
\text { country }\end{array}$ & Sleep measures & Physical activity measures & Main results \\
\hline $\begin{array}{l}\text { Paparrigopoulos } \\
\text { et al. }{ }^{8} \\
\text { Cross- sectional }\end{array}$ & $\begin{array}{l}\text { Adults }(18+ \\
\text { years }) \\
\mathrm{N}=1,005 \\
\text { Greece }\end{array}$ & $\begin{array}{l}\text { Questionnaire: Athens Insomnia } \\
\text { Scale (AIS), which is an 8-item } \\
\text { standardized self-assessment } \\
\text { psychometric instrument designed } \\
\text { for quantifying sleep difficulty } \\
\text { based on the ICD-10 criteria. }\end{array}$ & $\begin{array}{l}\text { Questionnaire: IPAQ. } \\
\text { Subjects with score on IPAQ less than } \\
30 \text { were characterized as physically } \\
\text { inactive. }\end{array}$ & $\begin{array}{l}\text { Inactive individuals presented odds } \\
1.42 \text { times higher to insomnia (CI } \\
\text { 95\%: 1.01-2.03). }\end{array}$ \\
\hline \multirow[t]{2}{*}{$\begin{array}{l}\text { Park et al. }{ }^{28} \\
\text { Cross-sectional }\end{array}$} & $\begin{array}{l}\text { Adults (18 to } \\
64 \text { years) } \\
\mathrm{N}=6,510 \\
\text { Korea }\end{array}$ & $\begin{array}{l}\text { Questionnaire: } \\
\text { a. "On average, how many hours } \\
\text { do you sleep each night on } \\
\text { weekdays?" } \\
\text { b. "During the past month, } \\
\text { how often have you had trouble } \\
\text { sleeping due to difficulty falling } \\
\text { asleep?" } \\
\text { c. "During the past month, } \\
\text { how often have you had trouble } \\
\text { sleeping because you often woke } \\
\text { up after falling asleep?" } \\
\text { d. "During the past month, } \\
\text { how often have you had trouble } \\
\text { sleeping because you woke up } \\
\text { too early and could not go back } \\
\text { to sleep?" } \\
\text { e. "During the past month, have } \\
\text { you ever woken up feeling tired } \\
\text { and not refreshed?" } \\
\text { Sleep duration was categorized in } \\
<5 \text { hours, 6hours, } 7 \text { hours, } 8 \text { hours } \\
\text { and } 9 \text { or more hours. } \\
\text { Reference: } 7 \text { hours } \\
\text { The presence of difficulty } \\
\text { initiating sleep, difficulty } \\
\text { maintaining sleep, early morning } \\
\text { awaking and non-restorative sleep } \\
\text { were defined by three or more } \\
\text { sleep-related difficulties per week. }\end{array}$ & $\begin{array}{l}\text { The PA was classified as follow: } \\
\text { "inactive", "minimally active" and } \\
\text { "health-enhancing". }\end{array}$ & $\begin{array}{l}\text { Individuals in health-enhancing category } \\
\text { presented odds } 1.44 \text { times higher to sleep } \\
5 \text { hours compared to } 7 \mathrm{~h} \text { sleepers (CI } \\
95 \%: 1.14-1.81 \text { ). }\end{array}$ \\
\hline & $\begin{array}{l}\text { Children ( } 2 \text { to } \\
7 \text { years) }\end{array}$ & & & \\
\hline Cross-sectional & $\begin{array}{l}\text { Italy, Estonia, } \\
\text { Cyprus, } \\
\text { Belgium, } \\
\text { Sweden, } \\
\text { Hungary, } \\
\text { Germany and } \\
\text { Spain }\end{array}$ & $\begin{array}{l}\text { 24-h recall (SACINA): } \\
\text { information of parents/guardian. } \\
\text { Sleep duration was used in } \\
\text { continuous way. }\end{array}$ & $\begin{array}{l}\text { Accelerometry: Actigraph GT1M and } \\
\text { ActiTrainer with cut-offs for moderate } \\
\text { to vigorous activity according to Sirard } \\
\text { et al. } \\
\text { Wore in waist for } 3 \text { days. } \\
\text { The variable generated was minutes of } \\
\text { MVPA. }\end{array}$ & No association. \\
\hline Pesonen et al..$^{50}$ & $\begin{array}{l}\text { Children (8 } \\
\text { years) } \\
\mathrm{N}=297 \\
\text { Finland }\end{array}$ & $\begin{array}{l}\text { Accelerometer: Actiwatch AW4, } \\
\text { in non-dominant wrist for } 7 \text { days } \\
\text { (with event maker). The generate } \\
\text { variable was standardized sleep } \\
\text { duration. }\end{array}$ & $\begin{array}{l}\text { Accelerometer: Actiwatch AW4, } \\
\text { in non-dominant wrist for } 7 \text { days } \\
\text { (prediction equation proposed by Heil } \\
\text { et al) } \\
\text { The generated variables were: } \\
\text { Mean of counts in entire day } \\
\text { (standardized); } \\
\text { MVPA 9a.m. to 6p.m. (1hours vs less); } \\
\text { MVPA 6.01p.m. to 9p.m. (1 hour vs. } \\
\text { less). }\end{array}$ & $\begin{array}{l}\text { Increase of } 1 \text { sd in mean of counts per } \\
\text { day, decreased } 0.30 \text { sd in sleep duration } \\
\text { (CI 95\%: }-0.36 ;-0.25 \text { ). } \\
\text { Do at least } 1 \text { hour of MVPA from 9a.m. } \\
\text { to } 6 \text { p.m. decreased } 0.21 \text { sd in sleep } \\
\text { duration (CI } 95 \%:-0.31 ;-0.12 \text { ). } \\
\text { Do at least } 1 \text { hour of MVPA from } \\
\text { 6.01p.m. to 9p.m. decreased } 0.16 \text { sd in } \\
\text { sleep duration (CI 95\%: }-0.27 ;-0.05 \text { ). }\end{array}$ \\
\hline
\end{tabular}

Continue... 


\begin{tabular}{|c|c|c|c|c|}
\hline Author, Design & $\begin{array}{l}\text { Population, } \\
\text { country }\end{array}$ & Sleep measures & Physical activity measures & Main results \\
\hline $\begin{array}{l}\text { Hoefelmann et } \\
\text { al. }^{63}\end{array}$ & $\begin{array}{l}\text { Workers } \\
\mathrm{N}=52,774 \\
\text { Brazil }\end{array}$ & $\begin{array}{l}\text { Questionnaire: } \\
\text { "How often do you think that you } \\
\text { sleep well?" } \\
\text { Answers sometimes, never and } \\
\text { rarely were classified as poor sleep } \\
\text { quality. } \\
\text { Answers always and almost always } \\
\text { were classified as good sleep } \\
\text { quality. }\end{array}$ & $\begin{array}{l}\text { Questionnaire: no information (leisure- } \\
\text { time only). } \\
\text { The generated variable was categorized } \\
\text { in "active" and "inactive". }\end{array}$ & $\begin{array}{l}\text { Inactive men presented odds to poor } \\
\text { sleep quality } 1.18 \text { times higher than } \\
\text { actives (CI 95\%: } 1.11-1.26 \text { ). } \\
\text { Women showed similar pattern with } \\
\text { odds of } 1.18 \text { too (CI 95\%: 1.07-1.31). }\end{array}$ \\
\hline Narang et al. ${ }^{51}$ & $\begin{array}{l}\text { Children and } \\
\text { adolescents (age } \\
\text { average }=14.2 \\
\text { years) } \\
\mathrm{N}=3,372 \\
\text { Canada }\end{array}$ & Questionnaire: PSQI. & $\begin{array}{l}\text { Questionnaire: no information. } \\
\text { The generated variable was categorized } \\
\text { into: "0-2 days/week", “3-4 days/week", } \\
\text { "5.7 days/week”. }\end{array}$ & $\begin{array}{l}\text { The means of PSQI scores decreased } \\
\text { according to increase in frequency of } \\
\text { PA indicating a better sleep quality ( } \mathrm{p}< \\
0.001 \text { ) } \\
\text { Mean of PSQI score in } 0--.2 \text { days of PA: } \\
7.4(5.9) \text {; } \\
\text { Mean of PSQI score in } 3-4 \text { days of PA: } \\
7.2(5.6) \text {; } \\
\text { Mean of PSQI score in } 5-7 \text { days of PA: } \\
6.3(5.6) \text {. }\end{array}$ \\
\hline Cross-sectional & $\begin{array}{l}\text { Adults }(40 \text { to } \\
70 \text { years }) \\
\mathrm{N}=68,832 \\
\text { China }\end{array}$ & $\begin{array}{l}\text { Questionnaire: } \\
\text { "In the past two years, how many } \\
\text { hours did you sleep each day } \\
\text { (including sleeping during the } \\
\text { day and night, but not including } \\
\text { time if you woke up between two } \\
\text { periods of sleep)?" } \\
\text { The answers were categorized } \\
\text { into: } \\
4 \text { hours; } 5 \text { hours; } 6 \text { hours; } 7 \text { hours } \\
\text { (reference); } 8 \text { hours; } 9 \text { hours and } \\
10 \text { hours. }\end{array}$ & $\begin{array}{l}\text { Questionnaire (no information). } \\
\text { The generated variable was "exercise } \\
\text { participation". }\end{array}$ & $\begin{array}{l}\text { Participation in exercise decreased the } \\
\text { odds of sleep at least } 4 \text { hours in } 0.84 \\
\text { times (CI } 95 \%: 0.76-0.92 \text { ) and sleep } \\
10 \text { hours or more in } 0.75 \text { times (CI } \\
95 \%: 0.68 ; 0.82 \text { ) compared to } 7 \text { hours. }\end{array}$ \\
\hline $\begin{array}{l}\text { Ekstedt et al. }{ }^{61} \\
\text { Cross-sectional }\end{array}$ & $\begin{array}{l}\text { Children ( } 6 \text { to } \\
10 \text { years) } \\
\mathrm{N}=1,231 \\
\text { Sweden }\end{array}$ & $\begin{array}{l}\text { Accelerometer: Actiwatch }{ }^{\circledR} \\
{[\text { AW], model 4, in wrist. }}\end{array}$ & $\begin{array}{l}\text { Accelerometer: Actiwatch }{ }^{\circledR}[\mathrm{AW}] \text {, } \\
\text { model 4, in wrist. } \\
\text { The generated variables were: } \\
\text { Total counts per minute and MVPA } \\
\text { (minutes). }\end{array}$ & No association. \\
\hline $\begin{array}{l}\text { Haario et al. } .^{20} \\
\text { Longitudinal }\end{array}$ & $\begin{array}{l}\text { Workers ( } 40 \text { to } \\
60 \text { years) } \\
\mathrm{N}=6,458 \\
\text { Finland }\end{array}$ & $\begin{array}{l}\text { Questionnaire: Jenkins Sleep } \\
\text { Questionnaire evaluating trouble } \\
\text { falling asleep, waking up several } \\
\text { times per night and trouble } \\
\text { staying a sleep. }\end{array}$ & $\begin{array}{l}\text { Questionnaire: } \\
\text { The respondents were asked about } \\
\text { their average weekly hours of physical } \\
\text { activity during leisure time or } \\
\text { commuting within the previous } 12 \\
\text { months in four grades of intensity: } \\
\text { walking, brisk walking, jogging and } \\
\text { running or equivalent activities. Each } \\
\text { intensity grade had five response } \\
\text { alternatives: no activity, } 0-1 / 2 \mathrm{~h} \text { per week, } \\
1 / 2-1 \text { h per week, } 2-3 \mathrm{~h} \text { per week and } \\
4 \mathrm{~h} \text { or more per week. Total physical } \\
\text { activity was measured by approximate } \\
\text { metabolic equivalent. } \\
\text { Physical activity was dichotomized } \\
\text { into physical inactivity (fewer than } \\
14 \text { MET-hours per week) or physical } \\
\text { activity (14or more MET-hours per } \\
\text { week). }\end{array}$ & $x^{2}$ \\
\hline
\end{tabular}

Continue... 


\begin{tabular}{|c|c|c|c|c|}
\hline Author, Design & $\begin{array}{l}\text { Population, } \\
\text { country }\end{array}$ & Sleep measures & Physical activity measures & Main results \\
\hline Inoue et al..$^{30}$ & $\begin{array}{l}\text { Elderly }(65+ \\
\text { years }) \\
\mathrm{N}=14,001 \\
\text { Japan }\end{array}$ & $\begin{array}{l}\text { Questionnaire: } \\
\text { Difficulty falling asleep lasting for } \\
30 \text { minutes or longer; } \\
\text { Waking up frequently during the } \\
\text { night; } \\
\text { Waking up too early in the } \\
\text { morning and being unable to go } \\
\text { back to sleep requiring the use of } \\
\text { hypnotics to fall asleep. } \\
\text { At least one symptom was } \\
\text { considerate insomnia. }\end{array}$ & $\begin{array}{l}\text { Questionnaire: } \\
\text { "How many days a week the subjects } \\
\text { spent } 30 \text { min or more walking } \\
\text { (hereafter referred to as Walk), } \\
\text { performing light work (Work; e.g., } \\
\text { office or home-based light work, } \\
\text { housework), and exercising (Exercise; } \\
\text { e.g., recreational/sporting activities)." } \\
\text { Walk, and exercise were classified into: } \\
\text { none, } 1-2 \text { days/week, } 3-4 \text { days/week, } \\
\text { and } 5 \text { or more days/week. }\end{array}$ & $\begin{array}{l}\text { Exercise } 5-7 \mathrm{~d} / \text { week decreased the odds of } \\
\text { difficulty maintaining sleep in } 0.66 \text { times } \\
\text { (CI 95\%: 0.51-0.85). }\end{array}$ \\
\hline Cross-sectional & $\begin{array}{l}\text { Undergraduate } \\
\text { students (age } \\
\text { average }=19.2 \\
(1.1) \\
\mathrm{N}=5,806 \\
\text { China }\end{array}$ & $\begin{array}{l}\text { Questionnaire: PSQI } \\
\text { Poor sleep quality: }>7 \text { points. }\end{array}$ & $\begin{array}{l}\text { Questionnaire: at least one day or night } \\
\text { of exercise (Physical activity rating scale } \\
\text { - 3/PARS-3). } \\
\text { The generate variable was categorized } \\
\text { into: } \\
\text { only day exercise; } \\
\text { only night exercise; } \\
\text { day and night exercise. }\end{array}$ & $\begin{array}{l}\text { Day exercise reduced the odds of poor } \\
\text { sleep quality in } 0.79 \text { times (CI } 95 \% \text { : } \\
0.65-0.96 \text { ) compared to not exercise } \\
\text { group. } \\
\text { Similar result to exercise day or night } \\
\text { with odds of } 0.74 \text { (CI 95\%: } 0.61-0.89 \text { ). } \\
\text { No association to night exercise } \\
\text { isolated. }\end{array}$ \\
\hline $\begin{array}{l}\text { Al-Hazzaa et al. }{ }^{52} \\
\text { Cross-sectional }\end{array}$ & $\begin{array}{l}\text { Children and } \\
\text { adolescents (age } \\
\text { average }=16.6 \\
(1.1)) \text {. }\end{array}$ & $\begin{array}{l}\text { Questionnaire: number of typical } \\
\text { sleeping hours per day (night and } \\
\text { day). } \\
\text { Sleep duration was categorized } \\
\text { into }<8 \text { h and } 8+\text { hours. }\end{array}$ & $\begin{array}{l}\text { Questionnaire: } \\
\text { The questionnaire collects information } \\
\text { on frequency, duration and intensity } \\
\text { of a variety of light, moderate and } \\
\text { vigorous-intensity PA during a typical } \\
\text { week. The questions covered transport, } \\
\text { household, fitness and sports activities } \\
\text { domains. PA were assigned metabolic } \\
\text { equivalent (MET) values based on the } \\
\text { compendium of PA. } \\
\text { Participants were classified into three } \\
\text { groups (low active, medium active and } \\
\text { high active) based on tertile of total } \\
\text { METs-min per week. }\end{array}$ & $\begin{array}{l}\text { Individuals in low PA category } \\
\text { presented odds } 1.33 \text { higher to adequate } \\
\text { sleep }(8+\mathrm{h}) \text { compared to high PA (CI } \\
95 \%: 1.08-1.61) \text {. }\end{array}$ \\
\hline Cross-sectional & $\begin{array}{l}\text { Adults }(23-60 \\
\text { years) } \\
\mathrm{N}=1,000 \\
\text { USA }\end{array}$ & $\begin{array}{l}\text { Questionnaire: } \\
\text { Overall sleep quality was } \\
\text { measured with one 4-item Likert- } \\
\text { type question with 'very good,' } \\
\text { 'fairly good,' 'fairly bad,' and 'very } \\
\text { bad' response options. } \\
\text { Answers fairly good/very good } \\
\text { were considerate good sleep. } \\
\text { Total sleep time (TST) was } \\
\text { assessed in hours and minutes "on } \\
\text { average worknights or weeknights } \\
\text { not including naps. } \\
\text { Adequate duration: } 7-8.5 \text { hours. }\end{array}$ & $\begin{array}{l}\text { Questionnaire: IPAQ + typical time } \\
\text { day. } \\
\text { The generated variables were: vigorous, } \\
\text { moderate and light exercise in morning, } \\
\text { afternoon, evening or none. }\end{array}$ & $\begin{array}{l}\text { Vigorous exercise in the morning } \\
\text { increased the odds of good sleep } \\
\text { quality in } 1.88 \text { times }(\mathrm{p}<0.001) \text { but } \\
\text { was not associated to sleep duration. } \\
\text { Moderate exercise in the morning } \\
\text { increased the odds of good sleep } \\
\text { quality in } 1.53 \text { times }(\mathrm{p}<0.05) \text { but was } \\
\text { not associated to sleep duration. } \\
\text { Light exercise in the evening increased } \\
\text { the odds of adequate sleep duration in } \\
1.77 \text { times }(\mathrm{p}<0.05) \text {. }\end{array}$ \\
\hline Cross-sectional & $\begin{array}{l}\text { Children and } \\
\text { adolescents (age } \\
\text { average }=15.6 \\
(2.1))\end{array}$ & $\begin{array}{l}\text { Questionnaire: Adolescent Sleep } \\
\text { Wake Scale. } \\
\text { Sleep habit information included } \\
\text { bedtime, wake-up time, and } \\
\text { sleep duration on weekdays } \\
\text { (from Monday to Friday) and on } \\
\text { weekends (Saturday and Sunday). } \\
\text { For the statistical analysis, the } \\
\text { number of minutes was divided by } \\
60, \text { multiplied by } 100 \text {, and added } \\
\text { to the number of hours to obtain a } \\
\text { metric variable. } \\
\text { Short sleep was defined as }<8 \\
\text { hours. }\end{array}$ & $\begin{array}{l}\text { Questionnaire: no information. } \\
\text { The generated variable was categorized } \\
\text { into: }<1 \text { and } \geq 1 \mathrm{~h} / \text { day in weekdays and } \\
\text { weekends. }\end{array}$ & $\begin{array}{l}\text { Less than } 1 \text { h of PA per day on weekends } \\
\text { increased the odds of short sleep in } 1.49 \\
\text { times compared to } 1 \text { h or more (CI } 95 \% \text { : } \\
1.11-1.99 \text { ) } \\
\text { PA on weekdays not was associated. }\end{array}$ \\
\hline
\end{tabular}

Continue... 
... continue

\begin{tabular}{|c|c|c|c|c|}
\hline Author, Design & $\begin{array}{l}\text { Population, } \\
\text { country }\end{array}$ & Sleep measures & Physical activity measures & Main results \\
\hline Longitudinal & $\begin{array}{l}\text { Elderly }(65+ \\
\text { years }) \\
\mathrm{N}=1,128 \\
\text { China }\end{array}$ & $\begin{array}{l}\text { Questionnaire: PSQI } \\
\text { Poor sleep quality: } \geq 6 \text { points. }\end{array}$ & $\begin{array}{l}\text { Questionnaire: Physical Activity Scale } \\
\text { for Elderly. } \\
\text { Totals for each category of activity were } \\
\text { divided by the mean into low (Lo) and } \\
\text { high (Hi) groups. Then, four groups } \\
\text { were created (Lo-Lo, Lo-Hi, Hi-Lo, } \\
\text { Hi-Hi(reference)) according to mean } \\
\text { splits for each activity in baseline and } \\
\text { follow-up. }\end{array}$ & $\begin{array}{l}\text { Lo-Lo group of leisure-time PA } \\
\text { present odds } 9.9 \text { times higher to } \\
\text { incidence of poor sleep quality (CI } \\
\text { 95\%: } 2.25-44.1 \text { ) compared to Hi-Hi } \\
\text { group. } \\
\text { Similar results to Hi-Lo group with } \\
\text { odds of } 8.73 \text { (CI } 95 \%: 1.90-40.2 \text { ) and } \\
\text { Lo-Hi group with odds of } 5.6 \text { (CI } \\
\text { 95\%: } 1.1-27.7 \text { ). }\end{array}$ \\
\hline Cross-sectional & $\begin{array}{l}\text { Undergraduate } \\
\text { students (age } \\
\text { average }=19.0 \\
(0.9)) \\
\mathrm{N}=1,106 \\
\text { China }\end{array}$ & $\begin{array}{l}\text { Questionnaire: PSQI } \\
\text { Poor sleep quality: }>5 \text { points. }\end{array}$ & $\begin{array}{l}\text { Questionnaire: } \\
\text { The frequency of PA (How often do } \\
\text { you sport and/or vigorous free play each } \\
\text { week with } 30 \text { minutes at least per day?) } \\
\text { was assessed by using the following } \\
\text { options: daily, } 5-6 \text { days/week, 3-4 days/ } \\
\text { week, } 1-2 \text { days/week, and less than } \\
\text { once per week. }\end{array}$ & $\begin{array}{l}\text { PA presented interaction with screen } \\
\text { time. } \\
\text { Adolescents with high PA and screen } \\
\text { time } \leq 2 \text { hours presented odds of poor } \\
\text { sleep quality } 0.51 \text { time lower compared } \\
\text { to group low PA and }>2 \mathrm{~h} \text { screen time } \\
\text { (CI 95\%: } 0.27-0.91 \text { ). }\end{array}$ \\
\hline Monteiro et al. ${ }^{33}$ & $\begin{array}{l}\text { Elderly }(65+ \\
\text { years }) \\
\mathrm{N}=689 \\
\text { Brazil }\end{array}$ & $\begin{array}{l}\text { Questionnaire: Nottingham } \\
\text { Health Profile. } \\
\text { Symptoms of insomnia: } \\
\text { Difficulty initiating sleep } \\
\text { difficulty maintaining sleep } \\
\text { early awakening } \\
\text { non-restorative sleep. }\end{array}$ & $\begin{array}{l}\text { Questionnaire: Minnesota Leisure } \\
\text { Activity Questionnaire. } \\
\text { At least one of following activities: } \\
\text { walking, gymnastics at home, gym, } \\
\text { ballroom dance. }\end{array}$ & No association. \\
\hline Cross-sectional & $\begin{array}{l}\text { Adolescents }(15 \\
\text { to } 17 \text { years) } \\
\mathrm{N}=2,432 \\
\text { Norway }\end{array}$ & $\begin{array}{l}\text { Questionnaire: } \\
\text { "When do you usually get out } \\
\text { of bed on a school day? and } \\
\text { When do you usually go to bed } \\
\text { on a school night? on a typical } \\
\text { weekday." } \\
\text { Short sleep was defined as }<8 \\
\text { hours. }\end{array}$ & $\begin{array}{l}\text { Questionnaire: } \\
\text { "How many hours per week do you } \\
\text { spend on doing sports/physical activity } \\
\text { in a way that makes you breathless or } \\
\text { sweat?' Response alternatives were: '0 } \\
\text { h, } 1-2 \text { h, 3-4 h, } 5-7 \mathrm{~h}, 8-10 \mathrm{~h} \text { and } 11 \\
\text { h or more. } \\
\text { For the statistical analysis, not } \\
\text { participating in } 60 \text { min of physical } \\
\text { activity every day was characterized as } \\
\text { health-risk behaviour. }\end{array}$ & $\begin{array}{l}\text { Did not participate in } 60 \text { min of physical } \\
\text { activity every day increased the odds } \\
\text { of short sleep in } 1.33 \text { times (CI } 95 \% \text { : } \\
1.05-1.68 \text { ). }\end{array}$ \\
\hline Tsunoda et al. ${ }^{64}$ & $\begin{array}{l}\text { Workers (age } \\
\text { mean }=48.9 \\
(11.4)) \\
\mathrm{N}=6,185 \\
\text { Japan }\end{array}$ & $\begin{array}{l}\text { Questionnaire: } \\
\text { Question about sleep duration. } \\
\text { Short sleep was defined as }<6 \\
\text { hours. }\end{array}$ & $\begin{array}{l}\text { Questionnaire: } \\
\text { Frequency, duration and intensity of } \\
\text { activities. } \\
\text { The final variables were: light, } \\
\text { moderate and vigorous PA at least once } \\
\text { a week. }\end{array}$ & $\begin{array}{l}\text { Light PA decreased the odds of short } \\
\text { sleep in } 0.86 \text { times (CI 95\%: 0.75- } \\
0.97 \text { ) } \\
\text { Vigorous PA decreased the odds of } \\
\text { short sleep in } 0.81 \text { times (CI 95\%: } \\
0.67-0.97 \text { ). }\end{array}$ \\
\hline Cross-sectional & $\begin{array}{l}\text { Adults }(20+ \\
\text { years }) \\
\mathrm{N}=40,535 \\
\text { Norway }\end{array}$ & $\begin{array}{l}\text { Questionnaire: } \\
\text { "How often during the last } 3 \\
\text { months has it occurred that you: } \\
\text { a. Had difficulties falling asleep } \\
\text { at night? } \\
\text { b. Woke up repeatedly during the } \\
\text { night? } \\
\text { c. Woke up too early and couldn't } \\
\text { get back to sleep? } \\
\text { d. Felt sleepy during the day?” } \\
\text { For all the four questions there } \\
\text { were three response options: } \\
\text { 'Seldom or never', 'Sometimes', } \\
\text { and 'Several times a week. } \\
\text { Subjects were diagnosed with } \\
\text { insomnia if answering 'several } \\
\text { times a week' on at least one of } \\
\text { the aspects. }\end{array}$ & $\begin{array}{l}\text { The generated variable was categorized } \\
\text { into: never or less than once a week } \\
\text { (physically inactive), once a week, two } \\
\text { or three times per week, or daily or } \\
\text { nearly daily. }\end{array}$ & $\begin{array}{l}\text { Inactive individuals presented odds of } \\
\text { insomnia } 2 \text { times higher than actives } \\
\text { (CI 95\%: 1.7-2.4). }\end{array}$ \\
\hline
\end{tabular}

Continue... 
... continue

\begin{tabular}{lll}
\hline Author, Design & $\begin{array}{l}\text { Population, } \\
\text { country }\end{array}$ & \multicolumn{1}{c}{ Sleep measures } \\
\hline Jiang et al. ${ }^{55}$ & $\begin{array}{l}\text { Children and } \\
\text { adolescents (age } \\
\text { average }=11.5)\end{array}$ & $\begin{array}{l}\text { Questionnaire: } \\
\text { Sleep duration was calculated as } \\
\text { the time lapse between bedtime } \\
\text { and wake up time. }\end{array}$ \\
Cross-sectional & $\mathrm{N}=6,247$ & $\begin{array}{l}\text { Sleep quality was assessed using } \\
\text { the Multidimensional Sub-health } \\
\text { Questionnaire of Adolescents }\end{array}$
\end{tabular}

Workers (age average in adults: 45.7 (8.8); age

Tsunoda et al. ${ }^{65}$ average in elderly $=65.6$

Longitudinal (4.7)).

$\mathrm{N}=7,061$

Japan

Undergraduate students (age

Wu et al. ${ }^{71} \quad$ average $=19.2$ )

Cross-sectional $\quad \mathrm{N}=4,747$

Questionnaire: PSQ

China

$\begin{array}{ll}\text { Yoon et al. }{ }^{13} & \begin{array}{l}\text { Adults (40 to } \\ 69 \text { years) }\end{array} \\ \text { Cross-sectional } & \mathrm{N}=84,094 \\ & \text { Korea }\end{array}$

Questionnaire:

"On average, how many hours of sleep did you get per day during the past year (including nap times)?”

Four response categories were given: $<6$ hours, $6-7$ hours (reference), 8-9 hours, and $\geq 10$ hours.
Physical activity measures

Main results
Questionnaire: After-school leisuretime physical activity (LPA) was measured by asking students how long they spent in light (e.g. walking), moderate (e.g. jogging, badminton) and vigorous (e.g. tennis, swimming) physical activity and summed to determine total LPA.

Questionnaire:

Frequency, duration and intensity of activities.

Moderate Low PA corresponds to approximately 3-5 METs, Moderate High PA corresponds to 5-7 METs, and Vigorous PA corresponds to $\geq 7$ METs.

Moderate Low PA, Moderate High $\mathrm{PA}$, and Vigorous PA were, respectively, categorized into dichotomous variables of "less than once a week" and "once a week or more.

Questionnaire:

"On how many of the past 7 days did you do exercises to strengthen or tone your muscles, such as push-ups, sit-ups, or weight lifting?' The responses range from0 to 7 days.

High PA was defined as at least three days per week of exercise.

The Physical Activity Rank Scale-3 (PARS-3) was used to assess the PA rank of the college students. The PARS-3 is a self-rated questionnaire that assesses PA rank over a 1-month time period. PA rank was measured according to the intensity, time and the following equation: PA rank = intensity $\times$ time $\times$ frequency. By PARS-3, The resulting score $(\leq 19$, 20-42 and $\geq 43$ ) was used to determine a low, medium or high PA rank, respectively.

\section{Questionnaire:}

"Do you do any sports regularly until you sweat?" frequency of exercise, respectively, with
Girls in secondary school presented a positive association of LPA and sleep duration $(B=0.059 ; p=0.030)$. No association to sleep quality and boys.
No association.

Individuals in high rank of PA presented odds 0.69 lower to poor sleep quality compared to low rank (CI 95\%: 0.49-0.99).

Individuals in high PA and $<2 \mathrm{~h}$ screen time (interaction) presented odds 0.48 lower to poor sleep quality (CI 95\%: 0.29-0.81)

For men, non-exercise group presented odds 1.48 times higher to long sleep $(\geq 10 \mathrm{~h}$ ) compared to exercise group (CI 95\%: 1.23-1.78)

For women, non-exercise group present odds 1.07 times higher to moderately long sleep (8-9h) compared to exercise group (CI 95\%: 1.03-1.12). Similar results to long sleep $(\geq 10 \mathrm{~h})$ with odds 1.26 (CI 95\%: 1.11-1.42).

No association to short sleep for both sexes.

Continue... 


\begin{tabular}{|c|c|c|c|c|}
\hline Author, Design & $\begin{array}{l}\text { Population, } \\
\text { country }\end{array}$ & Sleep measures & Physical activity measures & Main results \\
\hline Chang et al..$^{72}$ & $\begin{array}{l}\text { Undergraduate } \\
\text { students (18 to } \\
25 \text { years). } \\
\mathrm{N}=1,230 \\
\text { (Taiwan) China }\end{array}$ & $\begin{array}{l}\text { Questionnaire: PSQI } \\
\text { Poor sleep quality: } \geq 6 \text { points }\end{array}$ & $\begin{array}{l}\text { Questionnaire: } \\
\text { frequency, amount, intensity, time, and } \\
\text { satisfaction with exercise within the } \\
\text { past } 3 \text { months. } \\
\text { The final variable was categorized into: } \\
\text { lower (i.e., } \leq 1 \mathrm{~d} / \text { week or } 2.5 \mathrm{~h} / \text { week) } \\
\text { and higher (>1 d/week or } 2.5 \mathrm{~h} / \text { week). }\end{array}$ & No association after adjustment. \\
\hline $\begin{array}{l}\text { Felden et al. }{ }^{56} \\
\text { Cross-sectional }\end{array}$ & $\begin{array}{l}\text { Children and } \\
\text { adolescents (10 } \\
\text { to } 19 \text { years). } \\
\mathrm{N}=516 \\
\text { Brazil }\end{array}$ & $\begin{array}{l}\text { Questionnaire: } \\
\text { Time when going to sleep and } \\
\text { waking up on school days. } \\
\text { Short sleep was defined as }<8 \\
\text { hours. }\end{array}$ & $\begin{array}{l}\text { Questionnaire: no information. } \\
\text { The final variable was categorized into } \\
\text { "active/ insufficiently active". }\end{array}$ & No association. \\
\hline $\begin{array}{l}\text { Fusz et al. }{ }^{35} \\
\text { Cross-sectional }\end{array}$ & $\begin{array}{l}\text { Adults } \\
\mathrm{N}=455 \\
\text { Hungary }\end{array}$ & $\begin{array}{l}\text { Questionnaire: Athens Insomnia } \\
\text { Scale. } \\
\text { Insomnia was defined as } 10 \text { points } \\
\text { in scale. }\end{array}$ & $\begin{array}{l}\text { Questionnaire: no information. } \\
\text { The final variable was PA frequency } \\
\text { categorized into: no, never/ rarely/ } \\
\text { regularly. }\end{array}$ & $\begin{array}{l}\text { Regular exercise group present lower } \\
\text { mean of insomnia score }(p=0.011) \text {. }\end{array}$ \\
\hline $\begin{array}{l}\text { Hartescu et al. }{ }^{36} \\
\text { Longitudinal }\end{array}$ & $\begin{array}{l}\text { Elderly }(65+ \\
\text { years }) \\
\mathrm{N}=690 \\
\text { United } \\
\text { Kingdom }\end{array}$ & $\begin{array}{l}\text { Questionnaire } \\
\text { "Do you ever have problems } \\
\text { sleeping?" (i.e., problems getting } \\
\text { to sleep and/or staying asleep and/ } \\
\text { or waking too early), with five } \\
\text { response categories (never, seldom, } \\
\text { sometimes, often, all the time)". } \\
\text { If the respondent reported one } \\
\text { or more sleep problems "often" or } \\
\text { "all the time", and if that problem } \\
\text { had been experienced within the } \\
\text { previous week was considerate } \\
\text { insomnia. }\end{array}$ & $\begin{array}{l}\text { Questionnaire: } \\
\text { Levels of customary physical activity } \\
\text { likely to promote muscle strength, joint } \\
\text { flexibility, or stamina were assessed } \\
\text { using detailed activity inventories. } \\
\text { The amount of walking (purposeful } \\
\text { walking, shopping, and recreational } \\
\text { walking) in each hour was coded in } \\
\text { minutes per day. These were then } \\
\text { aggregated in minutes per week. } \\
(0 / 150 \text { min walking per week } / \geq \min \\
\text { walking per week). }\end{array}$ & No association \\
\hline Smagula et al. ${ }^{37}$ & $\begin{array}{l}\text { Elderly }(60+ \\
\text { years) } \\
\mathrm{N}=8,265 \\
\text { China }\end{array}$ & $\begin{array}{l}\text { Questionnaire: } \\
\text { “On the average, during the last } \\
\text { year, how many } \\
\text { hours in a day did you sleep } \\
\text { (including naps)?' Response } \\
\text { options were: } 5 \mathrm{~h} \text { or less; } 6 \mathrm{~h} ; 7 \mathrm{~h} \text {; } \\
8 \mathrm{~h} \text {; } 9 \mathrm{~h} \text { or } 10 \mathrm{~h} \text { or more. } \\
\text { Short sleep was defined as } \\
<6 \text { hours and long sleep as } \\
>8 \text { hours. }\end{array}$ & $\begin{array}{l}\text { Questionnaire: no information. } \\
\text { The final variable categorized PA into: } \\
\text { none/ up to 3hours/ } 4 \text { hours or more. }\end{array}$ & $\begin{array}{l}\text { Up to } 3 \text { hours of PA decreased odds } \\
\text { of long sleep in } 0.74 \text { times (CI } 95 \% \text { : } \\
0.65-0.84 \text { ) compared to no PA. } \\
\text { Similar results to } 4 \text { hours or more of } \\
\text { PA with odds of } 0.83 \text { (CI 95\%: } 0.26- \\
0.96 \text { ). }\end{array}$ \\
\hline
\end{tabular}

Continue... 


\begin{tabular}{lll}
\hline Author, Design & $\begin{array}{l}\text { Population, } \\
\text { country }\end{array}$ & \multicolumn{1}{c}{ Sleep measures } \\
\hline & & \\
Wu et al. ${ }^{38}$ & Adults (20+ & $\begin{array}{l}\text { Questionnaire: } \\
\text { "On average, how many hours } \\
\text { of sleep do you get in a 24-hour } \\
\text { period?" }\end{array}$ \\
Cross-sectional & N $=24,190$ & $\begin{array}{l}\text { Sleep duration was categorized } \\
\text { into: } \leq 5,6,7 \text { (reference), 8, or } \geq 9 \mathrm{~h} .\end{array}$
\end{tabular}

Questionnaire:

Levels of leisure-time PA were obtained

from the following questions: "How often do you do vigorous leisure-time physical activities for at least $10 \mathrm{~min}$ that cause heavy sweating or large increases in breathing or heart rate?" "About how long do you do these vigorous leisure-time physical activities each time?"

"How often do you do light or moderate leisure-time physical activities for at least 10 min that cause only light sweating or a slight to moderate increase in breathing or heart rate?". "About how long do you do these light or moderate leisure-time physical activities each time?"

Based on the quartiles of $\mathrm{PA}$ index, the variable is categorized as $\leq \mathrm{P} 25$, P25$\mathrm{P} 50, \mathrm{P} 50-\mathrm{P} 75$ and $>\mathrm{P} 75$.
Main results

Compared to $\mathrm{P} \leq 25$ of $\mathrm{PA}$ index, all other percentiles presented lower odds to sleep $\leq 5$ hours:

odds P25 = 0.72 (CI 95\%: 0.59-0.86) odds P25-P75 = 0.66 (CI 95\%: 0.550.79 )

odds $\mathrm{P}>75=0.60$ (CI 95\%: 0.49-0.79).

Compared to $\mathrm{P} \leq 25$ index of PA, P25-P75 and $\mathrm{P}>75$ index, presented lower odds to sleep 6 hours:

odds P25-P75 = 0.82 (CI 95\%: 0.73-

0.93)

odds $\mathrm{P}>75=0.82$ (CI 95\%: 0.72-0.94)

Compared to $\mathrm{P} \leq 25$ index of $\mathrm{PA}, \mathrm{P} 25-\mathrm{P} 75$

and $\mathrm{P}>75$ index, presented lower odds to

sleep 8 hours:

odds P25-P75 = 0.81 (CI 95\%: 0.730.90)

odds $\mathrm{P}>75=0.82$ (CI 95\%: 0.73-0.92)

Compared to $\mathrm{P} \leq 25$ index of $\mathrm{PA}, \mathrm{P} 25-\mathrm{P} 75$

and $\mathrm{P}>75$ index, presented lower odds to sleep $\geq 9$ hours:

odds P25-P75 = 0.70 (CI 95\%: 0.58-

0.83 )

odds $\mathrm{P}>75=0.64$ (CI 95\%: 0.52-078)

Questionnaire:

Participants were

asked if they participated in any

moderate or vigorous recreation

activities

and if they used a bicycle or walked

for transportation. Participants who reported engaging in any recreation PA

Adults (20 to Questionnaire:
65 years) "How much sleep do you usually get at night, on weekdays or workdays?"

Short sleep was defined as $\leq 6$

Cross-sectional

$$
\mathrm{N}=9,205
$$

USA hours.

were asked how many minutes per day in a typical day and how many days per week in a typical week they engaged in each type of activity

Recreation PA was categorized based on the physical activity recommendation for weekly activity: inactive ( 0 minutes/week), insufficiently active ( $>0$ to $<150$ minutes/week),

sufficiently active $(\geq 150$ to $<300$ minutes/week), and highly active $(\geq 300$ minutes/week).

Adolescents (12 Questionnaire:

Gong et al..$^{57}$ to 19 years) "On average night, how many $\mathrm{N}=10,796$ hours of sleep do you get on

Cross-sectional weekdays and weekend days?" Short sleep was defined as $<8$ China hours.
Questionnaire: no information.

Final variable was categorized as: Moderate PA at least 1 day in a week. Strength PA at least 1 day in a week.
No association with recreational PA.

Moderate PA was associated to odds 1.16 times higher to adequate sleep compared to no PA group (CI 95\%: 1.15-1.17)

Continue... 


\begin{tabular}{|c|c|c|c|c|}
\hline Author, Design & $\begin{array}{l}\text { Population, } \\
\text { country }\end{array}$ & Sleep measures & Physical activity measures & Main results \\
\hline Kakinami et al. ${ }^{58}$ & $\begin{array}{l}\text { Adolescents } \\
\text { and young } \\
\text { adults (12 to } 24 \\
\text { years) } \\
\mathrm{N}=658 \\
\text { Canada }\end{array}$ & $\begin{array}{l}\text { Questionnaire: } \\
\text { Quality: PSQI } \\
\text { Poor sleep quality } \geq 5 \text { points } \\
\text { Sleep duration: } \\
\text { "During the past month, what } \\
\text { time did you usually go to bed at } \\
\text { night?" } \\
\text { "During the past month, how long } \\
\text { has it usually taken you to fall } \\
\text { asleep at night?" } \\
\text { "During the past month, what } \\
\text { time did you usually get up in the } \\
\text { morning?" } \\
\text { Sleep quantity was represented by } \\
\text { the difference between the first } \\
\text { and third items, after subtracting } \\
\text { out the second item. } \\
\text { Sleep quantity was categorized as } \\
<7 \text { hours a } \\
\text { night, } 7-9 \text { hours a night } \\
\text { (reference), and } \geq 9 \text { hours. }\end{array}$ & $\begin{array}{l}\text { Questionnaire: IPAQ (leisure-time). } \\
\text { The generated variables were: } \\
\text { Total minutes of LPA, MPA and VPA; } \\
\text { PA recommendations ( } \geq 150 \text { minutes of } \\
\text { MPA, } \geq 75 \text { minutes of VPA. }\end{array}$ & No association. \\
\hline $\begin{array}{l}\text { Kitano et al. }{ }^{66} \\
\text { Longitudinal }\end{array}$ & $\begin{array}{l}\text { Workers (age } \\
\text { average = } 47.9 \\
(10.8)) \\
\mathrm{N}=3,621 \\
\text { Japan }\end{array}$ & $\begin{array}{l}\text { Questionnaire: PSQI' (only } \\
\text { question about self-perception of } \\
\text { sleep quality). } \\
\text { Poor sleep quality: answers bad } \\
\text { and very bad. }\end{array}$ & $\begin{array}{l}\text { Questionnaire: IPAQ(leisure time). } \\
\text { The final variables were: } \\
\text { insufficiently active: engaging in LTPA } \\
\text { less than } 10 \text { METs-h/week; weekend } \\
\text { warrior: engaging in LTPA at least } 10 \\
\text { METs-h/week; from } 1 \text { or } 2 \text { sessions, } \\
\text { and regularly active: engaging in LTPA } \\
\text { at least } 10 \text { METs-h/week; } \\
\text { from } 3 \text { or more sessions. }\end{array}$ & $\begin{array}{l}\text { Regular activity group presented a odds } \\
0.57 \text { times lower than no practice group } \\
\text { (CI 95\%: 0.42-0.78). }\end{array}$ \\
\hline $\begin{array}{l}\text { Sporndly-Nees } \\
\text { et al. }{ }^{40}\end{array}$ & $\begin{array}{l}\text { Adults }(20+ \\
\text { years }) \\
\mathrm{N}=5,062 \\
\text { Sweden }\end{array}$ & $\begin{array}{l}\text { Questionnaire: } \\
\text { Participants were asked to state } \\
\text { how much difficulty they have } \\
\text { "falling asleep in the } \\
\text { evening,", "waking several times } \\
\text { during the night," and "waking } \\
\text { too early and having } \\
\text { difficulty falling asleep again." A } \\
\text { five-point scale was used to score } \\
\text { the sleep quality, } \\
\text { ranging from score } 1 \text { ("none") to } 5 \\
\text { ("very severe"). } \\
\text { A score of } 4 \text { ("severe") or } 5 \text { ("very } \\
\text { severe") for any of the three items } \\
\text { confirmed symptoms of insomnia. }\end{array}$ & $\begin{array}{l}\text { Questionnaire: } \\
\text { Leisure-time physical activity was } \\
\text { assessed using a four-point scale } \\
\text { included the following: 1) spending } \\
\text { most of the time watching television, } \\
\text { reading, and being sedentary for most } \\
\text { of their leisure time; 2)engaging in } \\
\text { some physical activity, such as walking } \\
\text { and cycling, at least } 4 \text { hours per week; } \\
\text { 3) participating regularly in swimming, } \\
\text { jogging, tennis, and aerobic exercise, } \\
\text { for example, for } 3 \text { hours per week; and } \\
\text { 4) performing vigorous exercise and } \\
\text { competition in swimming, running, } \\
\text { football, handball, for example, several } \\
\text { times per week. } \\
\text { The level of physical activity was } \\
\text { categorized into three groups (low, } \\
\text { medium, and high). } \\
\text { Changes in PA from } 2000 \text { to } 2010 \text { were } \\
\text { following: } \\
\text { low-low (reference) } \\
\text { low-medium } \\
\text { medium-low } \\
\text { medium-medium } \\
\text { medium-high } \\
\text { high-low } \\
\text { high-medium } \\
\text { high-high. }\end{array}$ & $\begin{array}{l}\text { Changes in PA decreased the odds } \\
\text { to insomnia compared to group that } \\
\text { maintain low Pa in } 2000 \text { and } 2010 \text { except } \\
\text { group high-low } \\
\text { odds low-medium: } 0.53 \text { (CI 95\%: } \\
\text { 0.3-0.94) } \\
\text { odds low-high: } 0.17 \text { (CI 95\%: 0.03-0.81) } \\
\text { odds medium-low: } 0.83 \text { (CI 95\%: } \\
\text { 0.48-1.42) } \\
\text { odds medium-medium: } 0.53 \text { (CI 95\%: } \\
\text { 0.35-0.83) } \\
\text { odds medium-high: } 0.36 \text { (CI 95\%: } \\
\text { 0.21-0.64) } \\
\text { odds high-low: } 1.18 \text { (CI 95\%: 0.42-3.3) } \\
\text { odds high-medium: } 0.37 \text { (CI 95\%: } \\
\text { 0.21-0.66) } \\
\text { odds high-high: } 0.3 \text { (CI 95\%: 0.16-0.54). }\end{array}$ \\
\hline
\end{tabular}

Continue... 


\begin{tabular}{|c|c|c|c|c|}
\hline Author, Design & $\begin{array}{l}\text { Population, } \\
\text { country }\end{array}$ & Sleep measures & Physical activity measures & Main results \\
\hline Zhang et al. ${ }^{41}$ & $\begin{array}{l}\begin{array}{l}\text { Adults }(45+ \\
\text { years })\end{array} \\
\mathrm{N}=1,563\end{array}$ & $\begin{array}{l}\text { Questionnaire: PSQI } \\
\text { Poor sleep quality } \geq 6 \text { points. }\end{array}$ & $\begin{array}{l}\text { Questionnaire: no information. } \\
\text { The final variable was "exercise". }\end{array}$ & $\begin{array}{l}\text { No exercise group presented odds of } \\
1.79 \text { times higher to poor sleep quality } \\
\text { (CI 95\%: } 1.34-2.40) \text {. }\end{array}$ \\
\hline Wang et al. ${ }^{42}$ & $\begin{array}{l}\text { Adults (18-79 } \\
\text { years) } \\
\mathrm{N}=21,435 \\
\text { China }\end{array}$ & $\begin{array}{l}\text { Questionnaire: } \\
\text { "How many hours do you sleep } \\
\text { each night on average?" } \\
\text { Sleep duration was categorized } \\
\text { into: short sleep: }<7 \mathrm{~h} / \text { day; } \\
\text { medium sleep: } 7-9 \mathrm{~h} \text { /day } \\
\text { (reference); and long sleep: }>9 \mathrm{~h} / \\
\text { day. }\end{array}$ & $\begin{array}{l}\text { Questionnaire: no information. } \\
\text { The final variable was lacking exercise: } \\
\text { Participants who did not or seldom } \\
\text { (less than once per month). }\end{array}$ & $\begin{array}{l}\text { Lack of exercise group presented odds } \\
1.12 \text { higher to short sleep (CI 95\%: } \\
\text { 1.02-1.22). Lack of exercise also was } \\
\text { associated to long sleep with odds of } \\
1.30 \text { (CI 95\%: } 1.10-1.55 \text {. }\end{array}$ \\
\hline Lima \& Silva ${ }^{60}$ & $\begin{array}{l}\text { Adolescents (14 } \\
\text { to } 19 \text { years). } \\
\mathrm{N}=1,110 \\
\text { Brazil }\end{array}$ & $\begin{array}{l}\text { Questionnaire: } \\
\text { "Do you sleep well and feel } \\
\text { rested?" } \\
\text { The students had five response } \\
\text { options: almost never; seldom; } \\
\text { sometimes; with relative frequency } \\
\text { and almost always. } \\
\text { The perception of the quality } \\
\text { of sleep was categorized in the } \\
\text { appropriate quality of sleep (with } \\
\text { relative frequency; almost always) } \\
\text { and low quality of sleep (almost } \\
\text { never; rarely; sometimes). }\end{array}$ & $\begin{array}{l}\text { Questionnaire: Youth Risk Behaviour } \\
\text { Surveillance (YRBSS). } \\
\text { "During the last } 7 \text { days, on how many } \\
\text { days } \\
\text { have you been physically active for at } \\
\text { least } 60 \text { minutes per day? (considering } \\
\text { physical activity of moderate intensity } \\
\text { and/or vigorous)" } \\
\text { The final variable was categorized into: } \\
\text { not meet recommendations ( } 0-4 \text { days) } \\
\text { and meets recommendations ( } 5 \text { days } \\
\text { or more). }\end{array}$ & No association. \\
\hline $\begin{array}{l}\text { Gubelmann et } \\
\text { al. }{ }^{43} \\
\text { Cross-sectional }\end{array}$ & $\begin{array}{l}\text { Adults ( } 35 \text { to } \\
75 \text { years) } \\
\mathrm{N}=2,649 \\
\text { Switzerland }\end{array}$ & $\begin{array}{l}\text { Accelerometer: } \\
\text { GENEActive, in wrist by } 14 \text { days. } \\
\text { Sleep duration: Time with no } \\
\text { change in arm angle greater } \\
\text { than } 5^{\circ} \text { for } 5 \text { min or more during } \\
\text { predefined nocturnal sleep } \\
\text { window (21:00-9:00). } \\
\text { Short subjective sleep duration: } \\
\leq 6 \text { hours } \\
\text { Questionnaire: PSQI and } \\
\text { Insomnia Severity Index (ISI) } \\
\text { Poor sleep quality: PSQI } \geq 6 \\
\text { points } \\
\text { Insomnia: ISI } \geq 15 \text { points. }\end{array}$ & $\begin{array}{l}\text { Accelerometer: } \\
\text { GENEActive, in wrist by } 14 \text { days. } \\
\text { Participants were split into tertiles of } \\
\text { time spent in MVPA and classified as } \\
\text { low PA if they were in the first tertile } \\
\text { and as high PA otherwise. }\end{array}$ & No association. \\
\hline Cross-sectional & $\begin{array}{l}\text { Adolescents }(12 \\
\text { to } 18 \text { years) } \\
\mathrm{N}=481 \\
\text { Ireland }\end{array}$ & $\begin{array}{l}\text { Questionnaire: PSQI } \\
\text { Poor sleep quality: PSQI } \geq 6 \\
\text { points. }\end{array}$ & $\begin{array}{l}\text { Questionnaire: } \\
\text { Number of days which each participant } \\
\text { had accumulated at least } 60 \text { min of } \\
\text { moderate and vigorous PA during the } \\
\text { prior } 7 \text { days and for a typical week } \\
\text { classified as low (0-2 day/week), } \\
\text { moderate ( } 3-4 \text { day/week), or high ( } 5+ \\
\text { day/week). }\end{array}$ & $\begin{array}{l}\text { Moderate }(\mathrm{OR}=0.49 ; 95 \% \mathrm{CI}: 0.29- \\
0.81) \text { and high }(\mathrm{OR}=0.53 ; 95 \% \mathrm{CI} \text { : } \\
0.31-0.92) \mathrm{PA} \text { were associated with } \\
51 \% \text { and } 47 \% \text { lower odds of poor sleep } \\
\text { quality. }\end{array}$ \\
\hline Cross-sectional & $\begin{array}{l}\text { Undergraduate } \\
\text { students (18 to } \\
24 \text { years) } \\
\mathrm{N}=2,100 \\
\text { Croatia }\end{array}$ & $\begin{array}{l}\text { Questionnaire: PSQI } \\
\text { Poor sleep quality: } \geq 6 \text { points. }\end{array}$ & $\begin{array}{l}\text { Questionnaire: IPAQ } \\
\text { PA was categorized into: sufficiently } \\
\text { active: at least } 150 \mathrm{~min} / \text { week of } \\
\text { moderate PA ou } 75 \mathrm{~min} / \text { week of } \\
\text { Vigorous PA. }\end{array}$ & $\begin{array}{l}\text { Insufficiently active individuals } \\
\text { presented odds } 1.31 \text { timer higher to } \\
\text { poor sleep quality (CI 95\%: 1.04-1.64). }\end{array}$ \\
\hline
\end{tabular}

Continue... 


\begin{tabular}{|c|c|c|c|c|}
\hline Author, Design & $\begin{array}{l}\text { Population, } \\
\text { country }\end{array}$ & Sleep measures & Physical activity measures & Main results \\
\hline $\begin{array}{l}\text { Skarpsno et al. }{ }^{67} \\
\text { Cross-sectional }\end{array}$ & $\begin{array}{l}\text { Workers (18 to } \\
67 \text { years) } \\
\mathrm{N}=650 \\
\text { Denmark }\end{array}$ & $\begin{array}{l}\text { Questionnaire: } \\
\text { "How often during the last month } \\
\text { did you: have difficulties falling } \\
\text { asleep at night? and wake up too } \\
\text { early and couldn't get back to } \\
\text { sleep?". The response options were: } \\
\text { "never", "rarely", "sometimes", } \\
\text { "often", and "always" on both } \\
\text { questions. } \\
\text { Participants answering "often" or } \\
\text { "always" on one or both questions } \\
\text { were considered to have symptoms } \\
\text { of insomnia. }\end{array}$ & $\begin{array}{l}\text { Accelerometry: } \\
\text { Actigraph GT3X+, in thigh and the } \\
\text { upper back for } 6 \text { days. } \\
\text { Total physical activity was divided } \\
\text { into quartiles to obtain four exposure } \\
\text { groups: "very low", "low", "medium", } \\
\text { and "high". }\end{array}$ & No association to total PA or LPA. \\
\hline $\begin{array}{l}\text { Vézina-Im et } \\
\text { al. }{ }^{44}\end{array}$ & $\begin{array}{l}\text { Adult women } \\
\text { (18 to } 44 \\
\text { years) } \\
\mathrm{N}=9,749 \\
\text { Canada }\end{array}$ & $\begin{array}{l}\text { Questionnaire: } \\
\text { Sleep duration: } \\
\text { "How long do you usually spend } \\
\text { sleeping each night?" } \\
\text { Short sleep was defined as <7 } \\
\text { hours. } \\
\text { Sleep quality: } \\
\text { "How often do you have trouble } \\
\text { going or staying asleep?"; } \\
\text { "How often do you } \\
\text { find your sleep refreshing?" } \\
\text { "How often do you find it } \\
\text { difficult to stay awake when you } \\
\text { want to?" } \\
\text { These three questions generated a } \\
\text { score of sleep quality. }\end{array}$ & $\begin{array}{l}\text { Questionnaire: } \\
\text { "Have you done any of the following } \\
\text { (walking } \\
\text { for exercise, gardening or yard work, } \\
\text { swimming, bicycling, popular or social } \\
\text { dance, home exercises, ice hockey, ice } \\
\text { skating, in-line skating or rollerblading, } \\
\text { jogging or running, golfing, exercise } \\
\text { class or } \\
\text { aerobics, downhill skiing or } \\
\text { snowboarding, bowling, baseball } \\
\text { or softball, tennis, weight-training, } \\
\text { fishing, volleyball, basketball, soccer, } \\
\text { any other, no physical activity) in the } \\
\text { past } 3 \text { months?" } \\
\text { The final variable was exercise (yes/no). }\end{array}$ & No association. \\
\hline
\end{tabular}

PA = Physical activity LPA = Leisure physical activity; MVPA = Moderate to vigorous physical activity; MET = Equivalent metabolic; PSQI = Pittsburgh Sleep Quality Index; IPAQ = International Physical Activity Questionnaire; Sd = standardized deviation. 